\title{
Duration of Intrastate Wars of Attrition: The Causal Impact of Military Build-Ups
}

\author{
Andreas Mehltretter ${ }^{\star}$ and Paul W. Thurner ${ }^{\star \star}$
}

September 20, 2021

\begin{abstract}
Scientific knowledge on the effectiveness of governmental military build-ups to terminate intrastate conflicts is sparse and inconclusive. Developing a war-ofattrition framework, we derive the impact of governments' armaments on the duration of these conflicts: military build-ups, as reflected in inflows of major conventional weapons, enable the government to inflict costs onto its adversaries, forcing them to withdraw earlier from the conflict. This type of weapons is required in particular to project military power over larger distances and to fight rebels in remote areas. Using SIPRI arms transfer data for the first time in a disaggregated dyadic design, covering 418 government-rebel group dyads in 134 conflicts, we empirically corroborate the formal model's predictions. As endogeneity issues might arise when governments procure arms in anticipation of a protracted conflict, we ensure causal identification with an instrumental variable survival approach based on the Aalen additive hazards model.
\end{abstract}

Keywords: intrastate conflict, conflict duration, armament, causal design, instrumental variable model

* Department of Political Science, Ludwig Maximilian University Munich, Oettingenstr. 67, 80538 Munich, Germany, +49 892180 9066, andreas.mehltretter@gsi.uni-muenchen.de

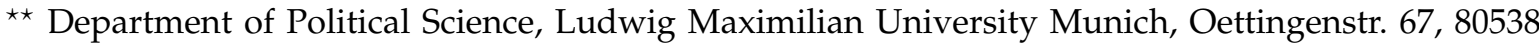
Munich, Germany, +49 892180 9080, paul.thurner@gsi.uni-muenchen.de

We acknowledge financial support by the German Foundation for Peace Research (grant no. FP 08/16 - SP 08/12-2015) and a scholarship of the Friedrich Ebert Stiftung for Andreas Mehltretter. We thank Maximilian Scherer and Maximilian Fasold for support with data management. 


\section{Introduction}

Delivery of weapons to conflict-prone countries is increasingly subject of debate in supplier countries. The arms industry pushes for sales opportunities, while public concerns arise over the negative impacts of these arms in the receiving countries. The conflict in Yemen provides a recent case for such discussions, as the largest importer of major weapons world-wide, Saudi Arabia, is seen responsible for escalating and prolonging the devastating conflict. The US administration, but also governments in Spain, Finland, or Germany were heavily criticized by domestic parliaments and the public for licensing arms exports to Saudi Arabia, as they are suspected of intensifying and perpetuating the conflict.

Although military capabilities are the-usually implicitly-theoretical rationale for explaining the degree of lethality and persistence of conflicts, they are rarely explicitly accounted for, neither in theory building nor in empirical applications. Kalyvas and Balcells (2010) present convincing arguments on how different configurations of relative military capabilities shape conflicts, and Balcells and Kalyvas (2014) examine their effects on intensity and duration. They find that conflicts with asymmetric distributions of capabilities, i.e. "irregular" conflicts, last longer than symmetric non-conventional and conventionally fought ones. However, only two studies provide inferential evidence on the specific consequences of governments' armament for the duration of intrastate conflicts. Moore (2012) finds that imports of major weapons are associated with more prolonged conflicts. In contrast, results from Caverley and Sechser (2017) indicate the opposite effect: focusing not on imports, but on so-called mechanization (cf. Lyall and Wilson 2009) as the ratio of military equipment to troops, they reveal that combined air and ground mechanization reduces the length of conflict spells. Thus, we have inconclusive, contradictory findings raising a puzzle on a fundamental and practically relevant question: are governmental military build-ups effective in terminating militarized intrastate conflicts?

Our contribution comprises three particular innovations: first, we adapt Powell's (2017) war-of-attrition model to derive consistent hypotheses for our context of militarized government-rebel dyads. According to the war-of-attrition framework, we argue that in each separate dyad, governments and the respective rebel group strategically determine how long they are withstanding the costs of military fighting. Second, we provide the first thorough empirical analysis of governmental military build-ups' effects on conflict duration, using arms imports as a valid proxy for such armament. By employing a dyadic empirical design, we can follow the theoretical perspective as closely as possible by disaggregating conflicts to separate state-rebel 
group relations. Third, we propose a solution to potential problems of demand endogeneity. Tchetgen et al. (2015) and Lergenmuller (2017) show that it is possible to implement an instrumental variable survival approach with the Aalen additive hazards model. This method allows us to estimate the actual causal impact of governmental military build-ups.

The empirical literature on the effects of armament and military strength on the duration of internal conflict did not relate to coherent formal frameworks so far. Unfortunately, this can lead to inconsistencies of arguments. For instance, Buhaug et al. (2009) argue that stronger rebels should fight shorter conflicts, while a greater distance between government stronghold and conflict site is expected to lead to more protracted conflicts-although a greater distance quite clearly also makes rebels relatively stronger. To derive consistent theoretical predictions, we therefore modify a stringent theoretical framework proposed by Powell (2017): in a war-of-attrition game, the government and each rebel group decide how long to fight in a conflict, and whenever one party quits, the conflict ends and the other party wins. The decision on how long to fight depends on the valuation of winning and on the costs that arise when fighting.

We argue that build-ups of military capability due to arms transfers enable the government to inflict higher costs on the rebels, and these costs cause the rebels to end the conflict earlier. In practice, major weapons are effective arms not only in large-scale battles, but also in asymmetric settings, e.g. when aircraft allow to target rebels in difficult-to-access areas (cf. Corum and Johnson 2003; Caverley and Sechser 2017). Especially when the conflict is located at a larger distance to the government stronghold, major weapons like transport helicopters or armored vehicles contribute significantly to the government's ability to project power over geographic distance (cf. Read 2010; Johnson 2017). Our empirical analyses demonstrate these mechanisms to be effective: we find that higher imports of major weapons lead to shorter conflict durations, but only when the conflicts are located in more remote areas.

The war-of-attrition framework allows us to derive further notable predictions: while most analyses using the Non-State Actors data Cunningham et al. (2013) find that weaker rebels fight longer conflicts (e.g. Cunningham et al. 2009; Buhaug et al. 2009), we expect stronger governments to be able to inflict higher costs onto such weaker rebel groups, causing them to quit the conflict earlier. In fact, we find clear empirical evidence-contradicting the findings derived from the Non-State Actors data-that conflicts last longer with relatively stronger rebels when using the troop ratio as an 
alternative measure of relative fighting capacity (cf. Hultquist 2013).

Furthermore, in wars of attrition, higher total costs are expected to lead to shorter conflicts, as both the government and the rebel group would decide to withdraw sooner. Thus, we predict that larger numbers of casualties should reduce the duration of a conflict (cf. Brandt et al. 2008; Balch-Lindsay et al. 2008). In contrast to the existing literature, we propose operationalizing these casualties as per-day value to match the measurement unit of conflict duration. Using this measure, we find robust evidence that higher intensity of conflicts reduces duration.

\section{Insights on the relationship between armament and duration of intrastate conflicts}

\subsection{Governmental military capabilities}

The opponents' military capabilities are essential determinants for how conflicts are fought and whether they can be terminated sooner or sustained longer (cf. Balcells and Kalyvas 2014). Surprisingly, only a few studies have empirically investigated the impact of the government's military endowment on conflict duration. Sislin and Pearson (2001) provide a descriptive analysis of 49 ethnic conflicts in the 1990s. They find that total imports are mostly higher in prolonged conflicts. However, they acknowledge that the endogenous demand for arms might drive this. Focusing exclusively on imports of major conventional weapons, Moore (2012) employs a Cox proportional hazard model. Using data from SIPRI in a sample of 94 conflicts from 1946 to 2002, he finds that increased volumes of major weapons imports of the government are associated with longer durations. Additionally, the analysis includes an indicator of "military quality," which is measured by the ratio of troops to military expenditure, as proposed by Bennett and Stam (1996), but does not show any statistically significant effects. Note that Moore only uses one observation per conflict, not allowing for any variations over time in the covariates and not discerning between different non-state adversaries involved in the same conflict. ${ }^{1}$

While not directly investigating the temporal extent of conflicts, Lyall and Wilson's (2009) study on 286 insurgencies between 1800 and 2005 indicates that increased ground mechanization, i.e. the ratio of military equipment to troop size, reduces the probability of government victories in intrastate conflicts. They argue that higher

\footnotetext{
${ }^{1}$ Additionally, the study's reliance on SIPRI's data for the measurement of rebels' military power is highly questionable, as noted below.
} 
mechanization leads to less direct contact with civilians and combatants, thereby losing access to valuable intelligence. Consequently, mechanization might have a prolonging effect, when governments would be less capable of ending conflicts earlier. Caverley and Sechser (2017) analyze the duration of 129 civil conflicts covering the period 1967-2003, coming to strikingly different conclusions. They focus on the mechanization of government forces, distinguishing between "ground" and "air" mechanization. Using data from the International Institute for Strategic Studies' Military Balance, they find that especially combined (i.e. interacted) mechanization leads to shorter conflicts, making ground and air mechanization strong complements. ${ }^{2}$

An alternative measure of governmental military capabilities is troop size, but results regarding its impact on conflict duration are also inconclusive: DeRouen and Sobek (2004) find a statistically significant effect of larger government troops sizes being associated with longer conflicts, while results in Brandt et al. (2008) show a conflictshortening effect of troop size, measured as a share of the country's population-and Sawyer et al. (2017) find no statistically significant effect at all.

Buhaug and Lujala (2005) and Buhaug et al. (2009) provide an essential argument concerning the mechanisms how military capabilities of the government are deployed: they argue that the distance between the government stronghold, usually operationalized by the country capital, and the battle site diminishes the relative capabilities of the government, as their military potential has to be projected over this distance. Empirically, they find that conflicts at larger distances from the capital exhibit longer durations.

Overall, the literature so far provides a series of contradictory results on the impact of governmental military build-ups on conflict duration. Furthermore, none of the discussed studies examining arms imports or endowments deal with potential endogeneity problems for empirically establishing a causal relationship. Whether these effects are truly causal or governments just decide to build up their military capacities in expectation of a longer conflict is thus an open question.

\subsection{Rebels' military capabilities}

Not only the military capabilities of governments shape conflict dynamics, but so do the capabilities of their adversaries. While strong rebels might be fought in an

\footnotetext{
${ }^{2}$ Although argued otherwise in the article, the effects found for air and ground mechanization separately are duration-shortening for almost all observed values of ground and air mechanization when taking the main effects of the interaction properly into account.
} 
open, and therefore decisive, battle, weaker groups employ strategies of so-called asymmetric or irregular warfare: guerrilla tactics and terrorism attacks enable rebels to fight for long times while avoiding direct confrontation with strong government troops (Butler and Gates 2009; Balcells and Kalyvas 2014) and amplifying information asymmetries (Walter 2009). Kalyvas and Balcells (2010) and Lockyer (2010) argue that rebels' specific warfare strategy is the direct consequence of the configuration of military power in a conflict: strong rebels and strong states fight conventional civil wars, weak rebels facing strong states employ guerrilla tactics, and when states and rebels both have limited capabilities, "symmetric non-conventional" warfare emerges (Kalyvas and Balcells 2010: 418). In turn, the type of warfare affects the duration of conflicts, as conventionally fought conflicts help to bring forth faster resolution, while guerrilla and symmetric non-conventional tactics allow rebels to evade decisive battles and to survive longer (Balcells and Kalyvas 2014).

In line with these arguments, Cunningham et al. (2009) suggest that greater rebel strength leads to shorter conflicts due to higher capacity to target the government. Prolonged conflicts might arise because "rebels are too weak to extract concessions or obtain negotiated settlements, yet too secure to easily be eradicated by governments" (Cunningham et al. 2009: 575). Using the Non-State Actors dataset (Cunningham et al. 2013), they find empirical evidence that "rebels at parity" with and "rebels stronger" than the government fight shorter conflicts. These results are corroborated in other studies using these data, e.g. Buhaug et al. (2009) and Wucherpfennig et al. (2012). Employing a different measure for relative capabilities of rebels based on the troop ratio of government and rebels, Hultquist (2013) shows that more symmetric capabilities distributions increase the probability of ceasefires or settlements. However, he finds no statistically significant relationship for government and rebel victories. Caverley and Sechser (2017) employ the Non-State Actors dataset in their analyses and do not encounter significant effects of their rebel strength variables too.

Only Moore (2012) measures the rebels' military capabilities more directly by using major conventional weapons transfers to rebels, for which SIPRI provides some data. However, this approach is highly problematic because SIPRI only records an extremely small number of those transfers to a very limited number of groups. Probably as a consequence, Moore's analysis exhibits no statistically significant effect of rebels' major weapons imports.

The military capabilities of rebels might also depend on the provision of external support. In general, interventions and military support are found to prolong con- 
flicts due to complicating bargaining processes and enabling rebels to pursue more enduring battles (Regan 2002; Balch-Lindsay and Enterline 2007; Brandt et al. 2008; Cunningham 2010; Cederman et al. 2013). However, Collier et al. (2004) find the opposite, namely a conflict-shortening effect of external support, whereas in Moore (2012) and Caverley and Sechser (2017), military assistance does not affect conflict duration. Using more granular data discerning between different types of support, Sawyer et al. (2017) show that more fungible support for rebels like funding and weapons prolongs conflicts, while direct intervention by sending troops leads to shorter conflicts.

In sum, existing research is throughout contradictory on the effect of governmental military capabilities: some studies find them to be associated with longer durations (Sislin and Pearson 2001; Moore 2012), and some with shorter durations (Caverley and Sechser 2017). None of these analyses deals with the potential issue of endogenous demand for arms in longer conflicts, thus disregarding the possibility of reverse causation. Also, measures of rebels' relative strength in conflicts do not exhibit consistent effects on duration throughout the literature.

\section{A war-of-attrition model of civil conflict duration}

\subsection{General description of the model}

Empirical literature researching the duration of intrastate conflict so far has, with a few exceptions (e.g. Fearon 2004), not made stringent use of formal models of conflict duration. In Buhaug et al. (2009), the contest success function (Tullock 1980; Hirshleifer 1988), predicting the probability of winning, was repurposed as a foundation for theoretical examinations on the length of fighting. Hirshleifer (2000) integrates the contest success function into a model where the government and the rebel group decide over their economic production and fighting investments. Due to decreasing marginal returns, weak rebel groups have a particularly high incentive to invest in fighting. In an extension of this logic, Buhaug et al. (2009) expect weaker rebels to fight longer conflicts. At the same time, they argue that a greater distance between government stronghold and conflict site should lead to prolonged conflicts, as such distances increase the relative power of the rebels. Thus, they put forward inconsistent hypotheses on how relative military capabilities of the government and rebels affect conflict duration.

To provide a stringent framework, we adopt a war-of-attrition model introduced by Powell (2017). As it directly relates input factors to the length of the conflict, it is 
tailor-made for the given context and allows for explicit predictions of how military capabilities and other conflict characteristics translate into the continuation or termination of fighting. In the model, the government fights against rebels until one side decides to quit. Each side chooses the right time to quit depending on costs that occur while fighting, inter alia casualties and material destructions, and the valuation they attribute to winning the conflict. Thus, the dynamics and duration of the conflict are completely determined by the respective costs and valuations, giving us an appropriate and flexible framework to investigate civil conflict duration theoretically. In the following, we lay out a model by Powell (2017) and discuss its comparative statics. Then, we provide the first thorough application of the model for deriving specific hypotheses on different factors' effects on the duration of intrastate conflict.

Formally, the two parties $i \in(g, r)$, government and rebels, are engaged in a conflict lasting for some time $t$. Both have distinct valuations of winning the conflict, $w_{i}$, which is private information to each side, but the opponent assumes it to be distributed according to $G_{i}\left(w_{i}\right)$. Fighting is costly due to the expenses of fighting itself as well as destruction and human losses. Both parties thus have to take their respective cost functions $c_{i}$, amounting to total costs $c_{i}$ t over the course of the conflict, into account for their decision when to quit.

This decision on the quitting time $t_{i}$ is based on the expected utility $U_{i}\left(t_{g}, t_{r}\right)$ the parties receive, which depends on who quits first: the winner, i.e. the party lasting longer in the conflict, gets her $w_{i}$, while the quitting opponent gets nothing. When both quit at the same time, both get half of their valuation of winning. According to Powell (2017: 221), the government's utility is thus given by

$$
U_{g}\left(t_{g}, t_{r}\right)= \begin{cases}-c_{g} t_{g} & \text { if } t_{g}<t_{r} \\ w_{g} / 2-c_{g} t_{g} & \text { if } t_{g}=t_{r} \\ w_{g}-c_{g} t_{g} & \text { if } t_{g}>t_{r} .\end{cases}
$$

The rebels' utility function $U_{r}\left(t_{g}, t_{r}\right)$ follows analogously.

To determine the duration of the conflict, we have to derive the optimal choices of quitting times for both parties, $\sigma_{i}\left(w_{i}\right)$, that depend on the valuation of winning. Intuitively, if winning, i.e. not quitting, the conflict is more valuable, higher costs will be endured for a longer time, leading to a prolonged conflict. Each player quits the conflict when her marginal costs exceed the expected marginal gains. The marginal gain will be the valuation of winning, but only when the adversary quits in the next instance. The expected marginal gain is thus $w_{i}$ times the probability the adversary will 
quit in the next instance, given it has not quit earlier. Over time, the marginal gain decreases, as the expected value for the adversary's valuation rises: when time passes, the other side will drop out of the conflict if it had a lower valuation; thus, only types with a higher valuation keep fighting. Essentially, the conflict occurs because valuation is private information, and only fighting reveals the adversary's valuation, or more precisely the lower bound of the distribution.

To be able to derive a unique solution for the optimal quitting times, Powell introduces two technical assumptions: first, $w_{i}$ is expected to be distributed exponentially with $G\left(w_{i}\right)=1-e^{\underline{w}_{i}-w_{i}}$. For clarity, we additionally assume that the lowest possible valuation $\underline{w}_{i}=0$. Second, there exists a very large $\bar{w}_{i}$, expected to occur with an "arbitrarily small probability" (Powell 2017: 222), above which the players are nonstrategic, always fighting until the other player ends the conflict.

Maximizing the expected utility then gives the equilibrium solution for each party's strategy. $\sigma_{i}^{*}\left(w_{i}\right)$ thus denotes the optimal time to quit fighting given a specific valuation of winning:

$$
\begin{aligned}
\sigma_{g}^{*}\left(w_{g}\right) & =\frac{\bar{w}_{g} \bar{w}_{r}}{c_{g}+c_{r}}\left(\frac{w_{g}}{\bar{w}_{g}}\right)^{1+c_{g} / c_{r}} \\
\sigma_{r}^{*}\left(w_{r}\right) & =\frac{\bar{w}_{r} \bar{w}_{g}}{c_{g}+c_{r}}\left(\frac{w_{r}}{\bar{w}_{r}}\right)^{1+c_{r} / c_{g}}
\end{aligned}
$$

Note that only the time of the side that quits first is relevant in determining the total duration of the conflict. Thus, there are two cases: either $\sigma_{g}^{*}\left(w_{g}\right) \geq \sigma_{r}^{*}\left(w_{r}\right)$, then the duration is given by the rebels' stopping time $\sigma_{r}^{*}\left(w_{r}\right)$, or $\sigma_{g}^{*}\left(w_{g}\right)<\sigma_{r}^{*}\left(w_{r}\right)$, then the duration is given by the government's, $\sigma_{g}^{*}\left(w_{g}\right)$. Using equations 2 and 3 , it can be shown that

$$
\sigma_{g}^{*} \gtreqless \sigma_{r}^{*} \Longleftrightarrow \bar{w}_{r}\left(\frac{w_{g}}{\bar{w}_{g}}\right)^{c_{g} / c_{r}} \gtreqless w_{r},
$$

giving the conditions under which either the government or rebel quitting time determines the conflict end (Powell 2017: 222).

When both sides put a similar value on winning, the cost ratio $c_{g} / c_{r}$ is central in determining who quits first. When the government is the stronger party, meaning the cost ratio favors the government, the rebels' quitting time determines the conflict duration, and vice versa. In our case of intrastate conflict, almost always the government is the stronger side, as demonstrated by Lockyer (2010: 97) and Buhaug et al. (2009: 550) and also indicated by the troop ratio (see section 4.2.3). Thus, $\sigma_{r}^{*}<\sigma_{g}^{*}$ 
meaning the rebels' quitting time determines the duration of the conflict.

\subsection{Comparative statics and general hypotheses}

How does the duration of the conflict change with changes in costs? The comparative statics presented in this section (cf. Powell 2017: 223) will allow us to derive general hypotheses on the effects of the cost ratio and total costs on the conflict duration.

As described above, $\sigma_{r}^{*}<\sigma_{g}^{*}$ is the relevant case for our analyses, meaning the rebels are expected to quit first and end the conflict. Thus, only effects on the rebels' quitting time are of interest and are presented in the following. To analyze how the cost ratio $\rho=c_{g} / c_{r}$ and total costs $k=c_{g}+c_{r}$ affect the conflict duration in this case, we conduct comparative statics of $\sigma_{r}^{*}\left(w_{r}\right)$ with respect to $\rho$ and $k$. Effects on $\sigma_{g}^{*}\left(w_{g}\right)$ follow analogously.

For changes in $c_{r}$ and accordingly the cost ratio $\rho$, higher (relative) costs for the rebels reduce conflict duration:

$$
\begin{aligned}
& \frac{\partial \sigma_{r}^{*}}{\partial \rho}=-\frac{\bar{w}_{g} \bar{w}_{r}}{k} \ln \left(\frac{w_{r}}{\bar{w}_{r}}\right)\left(\frac{w_{r}}{\bar{w}_{r}}\right)^{1+1 / \rho}>0 \\
& \frac{\partial \sigma_{r}^{*}}{\partial c_{r}}=-\frac{\bar{w}_{g} \bar{w}_{r}}{\left(c_{g}+c_{r}\right)^{2}}\left(\frac{w_{r}}{\bar{w}_{r}}\right)^{1+c_{r} / c_{g}}+\frac{\bar{w}_{g} \bar{w}_{r}}{c_{g}+c_{r}} \ln \left(\frac{w_{r}}{\bar{w}_{r}}\right)\left(\frac{w_{r}}{\bar{w}_{r}}\right)^{1+c_{r} / c_{g}}<0
\end{aligned}
$$

whenever $\frac{w_{r}}{\bar{w}_{r}}<1$, i.e. for all strategically planning rebels.

Intuitively, the rebels' expectation for the valuation of the government $\mathbb{E}_{t}\left(w_{g}\right)$ increases over the course of the conflict, as governments with low $w_{g}$ would drop out and end the conflict. Marginal costs $c_{r}$ occur at a constant rate, so the rebel groups quit the conflict as soon as marginal expected gains no longer exceed the marginal costs. In a situation with higher costs $c_{r}^{\prime}$ for the rebels, and thus a less favorable, i.e. lower, cost ratio $\rho^{\prime}$, costs overtake expected gains earlier, leading the rebels to end the conflict earlier.

\section{Figure 1 to appear here}

We depict this relationship between conflict duration and the cost ratio in figure 1 . It plots both quitting times $\sigma_{g}^{*}$ and $\sigma_{r}^{*}$ of the government and rebels depending on the cost ratio $\rho$, given their valuations of winning $\left(w_{r}>w_{g}\right.$ here for illustration purposes). As derived formally above, the rebels quit the conflict later with increasing $\rho$, i.e. relatively lower costs for the rebel side, and the government quits the conflict 


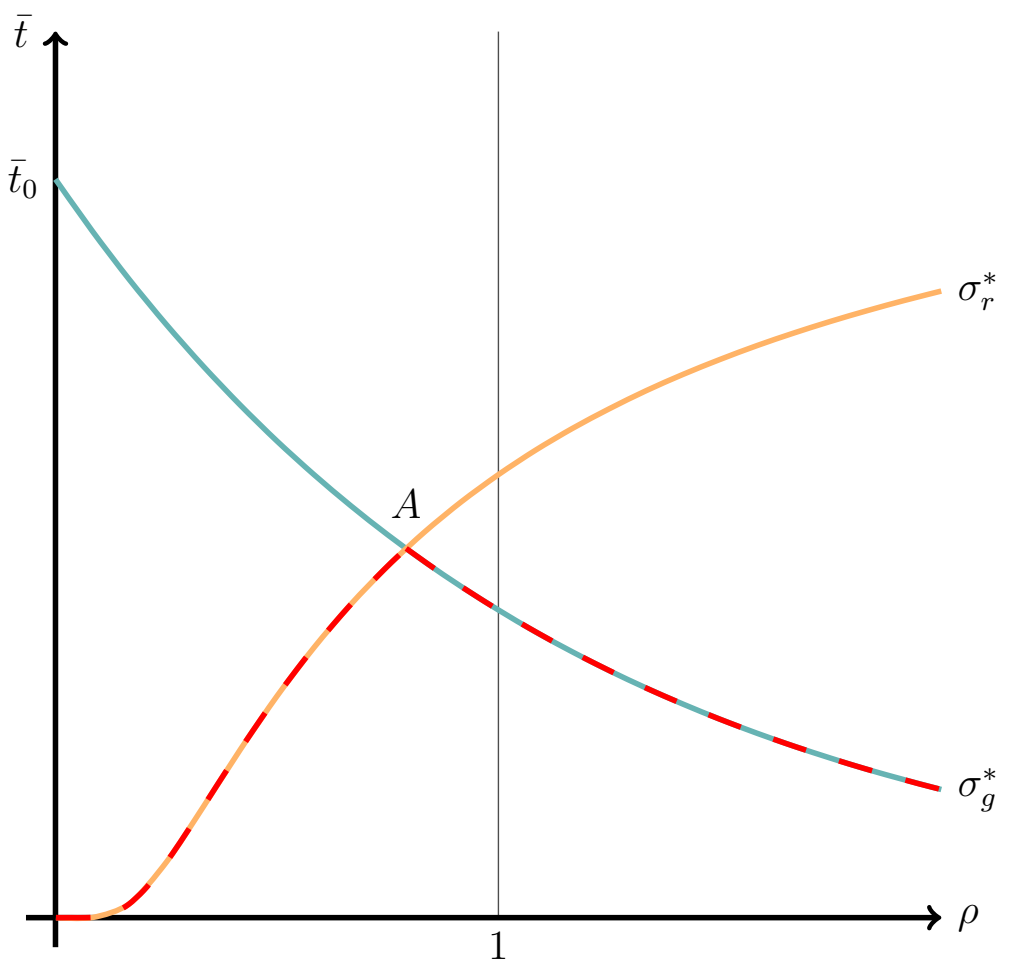

Figure 1: Quitting times $\bar{t}$ depending on cost ratio $\rho$

later with decreasing $\rho$, as this means decreasing relative costs for the government side.

The conflict ends when at least one conflict party decides to withdraw from the conflict. Thus, conflict duration is given by the quitting time of the party that quits first. In figure 1, the dashed red line represents the conflict duration. For $\rho$ left to the point $A, \sigma_{r}^{*}<\sigma_{g}^{*}$ means that the conflict duration is determined by the rebels' quitting time, which is increasing in $\rho$. For $\rho$ right to $A$, the government decides to quit first, and $\sigma_{g}^{*}$ thus determines conflict duration. At point $A$, both quit the conflict at the same time, which is the case for $\rho=\ln \left(\frac{w_{r}}{\bar{w}_{r}}\right) / \ln \left(\frac{w_{g}}{\bar{w}_{g}}\right)$, leading to the longest possible conflict duration. In a symmetric setting where $w_{g}=w_{r}$, the longest duration is reached for a symmetric cost ratio $\rho=1$, as Powell (2017: 223) notes.

As argued above, in intrastate conflicts, the government usually is the stronger party, i.e. it has the more favorable cost ratio. Assuming the valuations of both sides are relatively similar, the intrastate conflict situation is best described by the part of figure 1 left to point $A$. Here, an increase in $\rho$, meaning the cost ratio is becoming less favorable to the government, leads to a longer conflict duration, as we derived formally in equation 5. We can thus state the following general corollary (Powell 2017: 223): 
Corollary 1. Higher costs for the government, i.e. a cost ratio less favorable to the government, lead to longer conflicts, whereas higher costs for the rebels lead to shorter conflicts.

Turning to total costs, a higher $k$ always leads to shorter conflicts (ibid.):

$$
\frac{\partial \sigma_{r}^{*}}{\partial k}=-\frac{\bar{w}_{g} \bar{w}_{r}}{k^{2}}\left(\frac{w_{r}}{\bar{w}_{g} r}\right)^{1+1 / \rho}<0
$$

Corollary 2. Higher total costs lead to shorter conflicts.

\subsection{Costs and valuations in civil conflict}

On the foundation of the general predictions from Powell (2017), we can now provide the first encompassing application of the model to an empirical question in this section. In the war-of-attrition model, conflict duration is essentially determined by the costs $c_{g}, c_{r}$, which the government and rebel side suffer during conflict, and their ratio $\rho$. To capture the wide variety of factors that affect these costs, we understand costs not only as directly measurable losses, like fatalities, but also in a broader sense as the capabilities that allow one side to inflict costs on the other side.

The cost ratio $\rho$ thus depends on the military capabilities and consequently on either side's abilities to inflict costs on the other side. Specifically, armament $A$ should raise the fighting costs of the rebels $c_{r}$, as this is the main reason the government procures military equipment in the first place, although they might also raise financial costs for the government. Distance $d$ between the government stronghold, i.e. the capital, and the conflict might reduce the effective military capabilities deployed at the fighting site and thus decrease the relative costs of rebels. We lay out the mechanisms in more detail in the next section.

In contrast to distance, a troop ratio $T$ more favorable to the government side positively affects the government's capabilities and thus increases the relative costs for rebels. Taking these factors as inputs to the costs occurring to both sides, the cost ratio can be defined as a function $\rho(\bar{A}, \vec{d}, \bar{T})$. As a higher $\rho$ in the civil conflict setting, where the government is the stronger party, increases conflict duration, we can derive the following hypothesis:

Hypothesis 1. Factors raising the government's capabilities to inflict costs on the rebel side, i.e. arms procurement and a favorable troop ratio, lead to shorter conflicts, while factors weakening the capabilities, i.e. distance between the capital city and the conflict site, prolong conflicts. 
Fighting costs of the government $c_{g}$ are correspondingly affected by the capabilities of the rebel side. External support $X$ directly strengthens these capabilities and should result in higher costs for the government (Schulhofer-Wohl 2020). Mountainous terrain $m$ provides opportunities for rebels to hide and elude government forces, rendering effective fighting more costly for the government (Fearon and Laitin 2003; Brandt et al. 2008; Buhaug et al. 2009). Larger populations $P$ offer possibilities to retreat and more potential for rebel recruitment (Fearon and Laitin 2003), lowering the relative costs of the rebels. Groups that conduct terror attacks $Z$ can inflict costs on the government, but are challenging to target, leading to a cost ratio less favorable to the government and thus prolonging conflicts (Butler and Gates 2009). Using the augmented cost ratio function $\rho(\vec{A}, \stackrel{+}{d}, \vec{T}, \stackrel{+}{X}, \stackrel{+}{m}, \stackrel{+}{P}, \stackrel{+}{Z})$, and the fact that a higher $\rho(\cdot)$ prolongs conflicts leads to the following hypothesis:

Hypothesis 2. Factors raising the rebels' capabilities to inflict costs on the government side, i.e. external support, mountainous terrain, larger populations, and terrorist tactics, lead to longer conflicts.

Given a specific cost ratio, costs of government and rebels also affect the conflict duration due to total costs $k$, with higher $k$ leading to shorter conflicts. Casualties in a conflict can be interpreted as such costs (Brandt et al. 2008; Balch-Lindsay et al. 2008). Then, more intense conflicts should end earlier. Similarly, when conflict negatively impacts the economy, increased economic costs should lead to shorter conflicts. As governments in democracies face audience costs, meaning they are held responsible for the costs of fighting, we expect democracies to fight shorter conflicts (Stam 1996; Filson and Werner 2004).

Hypothesis 3. Higher total costs, as measured by casualties and reductions of economic welfare, lead to shorter conflicts.

Hypothesis 4. Higher valuations of costs, as is the case for democracies, lead to shorter conflicts.

Additionally, the model predicts that parties with higher valuations of winning fight longer conflicts, given costs (Powell 2017: 222). If a group is politically excluded, we might expect that conflict success is valued relatively higher, as political paths to reach its goals are blocked (cf. Cederman et al. 2013).

Hypothesis 5. Higher valuations of winning, as are presumed for politically excluded groups, lead to longer conflicts. 
Table 1: Overview of expected effects

\begin{tabular}{lcc} 
Factor & Theoretical mechanism & $\begin{array}{c}\text { Expected effect } \\
\text { on duration }\end{array}$ \\
\hline $\begin{array}{l}\text { Arms procurement } \\
\text { Troop ratio favorable to the government }\end{array}$ & relative costs for rebels + & - \\
\hline $\begin{array}{l}\text { Distance } \\
\begin{array}{l}\text { Mountainous terrain } \\
\text { Terrorist tactics }\end{array}\end{array}$ & relative costs for government + & + \\
\hline $\begin{array}{l}\text { External support to the rebel group } \\
\text { Population }\end{array}$ & relative costs for rebels - & + \\
\hline $\begin{array}{l}\text { Casualties } \\
\text { Economic losses }\end{array}$ & total costs + & - \\
\hline Democracy & valuation of costs + & - \\
\hline Group is politically excluded & valuation of winning + & +
\end{tabular}

Table 1 to appear here

To allow for an overview of the theorized mechanisms and effects, table 1 lists the expected effects from all hypotheses presented above.

\subsection{Armament, distance and the projection of power}

Armament in the form of arms imports can be interpreted as additions to a government's multidimensional military capabilities, lifting constraints of the existing military endowments in specific dimensions, like ground transport, intelligence, or airpower. Since only a few countries are able to produce major weapons and other military technology on their own, governments will decide to import a portfolio of arms that is tailored to the conflict environment their military capabilities are used in. This allows them to benefit from the usefulness of specific types of weapons in different conflict scenarios. In the perspective of the war-of-attrition model presented above, arms imports thus enhance the government's capabilities to inflict costs on the rebel group.

Research on conflict severity by Mehrl and Thurner (2020) has shown that armament with MCW can lead to higher intensity, meaning they provide and are used as effective fighting tools-which is why a government chooses to obtain them in the first place. Smith and Toronto (2010) demonstrate that especially well-equipped ground troops are very effective in counterinsurgency settings. Research for the US military concludes that in combination with matching tactics, tanks, and other ground armor can be a decisive factor for effective warfare, including in irregular wars and terrain difficult to maneuver (Johnson and Gordon IV 2010; Rogers 2012). Deployment of airpower might require an appropriate strategy, but can be very useful in con- 
ventional conflicts as well as in combating rebels in "small wars" and insurgencies (Corum and Johnson 2003; Dunlap Jr. 2008). Caverley and Sechser (2017) argue that combined mechanization, i.e. the combination of both well-equipped ground and air forces, in particular leads to shorter conflict. However, their estimates actually show that both types independently already reduce duration.

How effectively the government can fight in battles depends crucially on the conflict site location and its capabilities to project its military power to the conflict site. Boulding (1962) introduced the concept of a loss-of-strength gradient in international conflicts, which Buhaug et al. (2009) adopt for the intrastate conflict case: the distance between the government stronghold, operationalized by the country's capital city (cf. Buhaug and Gates 2002), and the conflict location, reduces the relative military capabilities of the government. Distance can function as a proxy for diminishing government authority in remote areas (Herbst 2000), less local knowledge, and lack of support from the local population (Buhaug et al. 2009). Primarily, distance is an obstacle that must be overcome before the government can fight in a conflict, as all fighting equipment, troops, and supplies have to be transported to the conflict site, and weaponry with a larger range has to be deployed. Thus, distance in general prolongs conflicts due to reduced relative capacities of the government (cf. Buhaug et al. 2009; Buhaug 2010).

Importantly, we argue that armament with MCW increases the government's capabilities to project its military power over distance, as arms can be an effective tool to overcome the challenges of fighting at remote conflict sites. First, imports of major conventional weapons can provide the necessary mobility to transfer troops and other equipment to the battlefield (cf. Caverley and Sechser 2017). Transport aircraft and helicopters (Read 2010) as well as armored vehicles (Johnson 2017) enable fast and extensive transportation, reducing the negative impact of distance. Second, the outreach of the government's military can be sufficiently extended by importing attack helicopters and aircraft and long-range missiles that allow fighting a conflict more distant from military bases (Johnson 2017; Caverley and Sechser 2017; Read 2010). Third, in conflicts at larger distances, reliable intelligence is increasingly important to fight effectively. Aircraft, helicopters, drones, and satellites that can provide such information are thus even more valuable for deploying military capabilities in distant conflicts (cf. Tucker 2014).

At the same time, arms procurement often poses a significant financial burden, as framed in the well-known guns-versus-butter trade-off from Powell (1993). While not all imports have to be paid for one-to-one in financial terms, especially after 
the Cold War, the arms trade was commercialized (Brzoska 2004). Therefore, arms imports not only enhance a government's military capabilities, but also imply substantial financial costs (cf. SIPRI nd; Holtom et al. 2012). In addition to the acquisition costs, major conventional weapons necessitate significant maintenance costs. Costs of importation have thus to be outweighed by their benefits in fighting to overall improve the cost ratio in favor of the government. This depends crucially on the fighting effectiveness of MCW. As argued above, we expect MCW to be especially effective in projecting power over longer distances, meaning the conflict-shortening effect on the cost ratio increases with the distance between the government stronghold and the conflict site.

Hypothesis 6. Imports of MCW are effective tools to project the government's power over distances and therefore reduce the duration of conflicts at larger distances.

\section{Research design and methods}

\subsection{The dyadic design}

Following the contributions by Cunningham et al. (2009) and Cederman et al. (2009), we employ a dyadic dataset design, thus matching the dyadic perspective of the war-of-attrition framework as closely as possible. On one side of each conflict dyad is a state government, and on the other side stands a non-state group, meaning we exclude conflicts without government involvement, and conflicts with multiple rebel groups involved are disaggregated into multiple dyads. Making conflict dyads and not conflicts our unit of analysis enables us to include group-specific covariates in our analysis, e.g. troop size or external support. Additionally, the composition of the government's adversaries in a conflict might change when it achieves an agreement with or victory over one involved group, but not with all groups to end the conflict as a whole.

To allow for time-varying covariates, a single observation in our dataset usually is a dyad-year, as all included covariates only feature yearly updates. However, the first and last observation of a conflict-dyad can comprise less than one year of duration when the conflict-dyad's start date is after January 1 and when the end date is before December 31. As usually in dyadic analyses, the unit of time in our analyses is days, not years, especially to account for shorter conflicts.

Data on the duration of conflicts and the respective warring parties is provided by the Armed Conflict Dataset (version 18.1) from the Uppsala Conflict Data Pro- 
gram/Peace Research Institute Oslo (UCDP/PRIO) (Harbom et al. 2008; Pettersson and Öberg 2020). Our analyses cover 134 unique conflicts between 1951 and 2010, with durations of conflict dyads ranging from 1 day to 14732 days (Government of Myanmar against the Communist Party of Burma). A conflict is recorded by UCDP/PRIO when it reaches at least 25 battle-related deaths in a calendar year. To avoid bias with regard to conflicts that never reach 25 deaths and are therefore not part of the dataset, we use the second start date provided by the Armed Conflict Dataset that marks the date the 25 battle-deaths mark is reached. ${ }^{3}$

As laid out in the theory section above, we focus our analyses on factors that affect the costs $c_{r}$ and $c_{g}$ and thus the cost ratio $\rho$, most notably the military capabilities that allow one side to increase conflict costs for the other side.

\subsection{Data}

\subsubsection{The main independent variables: arms imports}

To operationalize the relative build-up of military capacity on the government side, we use arms trade data provided by the Stockholm International Peace Research Institute's (SIPRI) Arms Transfer Database ${ }^{4}$ that records trades of major conventional weapons (MCW). ${ }^{5}$ SIPRI measures trade volumes by so-called trend-indicator values (TIV) that allow comparing transferred military capabilities based on production costs, but adjusted for inflation, wear, and age of the arms at the time of transfer.

SIPRI covers a wide range of MCW types. Following Pamp et al. (2018), we differentiate between weapons that usually cannot be employed in intrastate wars-namely air-defense systems, anti-submarine weapons, and ships-and those employed in intrastate wars - namely aircraft, armored vehicles, artillery, and missiles.

Trades of MCW often exhibit years-long spans between order and delivery. While orders might already constitute signals to rebel groups, the effect on military capacity only realizes when the weapons are delivered. To smooth out these discrepancies, we use the 3- and 5-year moving average of $t-1$ to $t-3 / t-5$ additionally to

\footnotetext{
${ }^{3}$ Note that conflicts/conflict dyads do not have to be observed over their whole time to enter the analysis, allowing e.g. for right-censoring when conflicts are not yet terminated at the end of our dataset's time span.

${ }^{4}$ Data of the SIPRI Arms Transfer Database can be retrieved at https://www.sipri.org/ databases/armstransfers.

${ }^{5}$ The Norwegian Initiative on Small Arms Transfers (see http://nisat.prio.org/TradeDatabase/) provides data on small arms and light weapons imports, but these are only available in reliable quality after the Cold War, with light weapons transfer data starting only in the 2000s (cf. Lebacher et al. 2021).
} 
lagged imports. Note that the averaged values can also be interpreted as a measure of arms build-ups, as they are just a rescaled version of the sum of imports over the preceding three or five years. In comparison, the lagged variable specification rather operationalizes the lifting of specific, binding constraints in a government's arms portfolio.

\subsubsection{Distances}

Following Buhaug and Gates (2002) and Buhaug et al. (2009), we operationalize the government stronghold as the country's capital city to derive a distance to the conflict site. To calculate this distance between the capital city and the conflict, we use two different datasets on conflict locations, the PRIO Conflict Site dataset (Buhaug and Gates 2002), covering conflicts from 1946 to 2005, and the UCDP Georeferenced Events dataset (Pettersson and Öberg 2020; Sundberg and Melander 2013), starting in 1989. For conflicts only covered by the PRIO dataset, we calculate the geodesic, i.e. beeline, distance, between the capital and the "conflict center" as provided by the dataset, which is the same for all dyads in a conflict in a given year. When data from UCDP is available, we can conduct more detailed calculations. As UCDP provides geolocations for every conflict event, we compute the geodesic distance for each event separately and use the mean of all events in a dyad-year as value for the distance variable.

\subsubsection{Additional operationalizations of costs and valuations}

The costs that occur during fighting are primarily shaped by the military capabilities and relative power of both government and rebels. To account for the distribution of power in a conflict, we use the ratio of government troops to rebel troops. This is the most direct possible operationalization of the cost ratio. Such a troop ratio was proposed in a similar form by Wood (2010) and Hultquist (2013). To account for a potentially non-linear effect of large asymmetries (the largest being 40000:1 in favor of the government), we use a logarithmic rescaling of the ratio. The data for the rebel troops is taken from the UCDP Conflict Encyclopedia (Uppsala Conflict Data Program 2018), while data for government troops is taken from the Correlates of War's (COW) National Material Capabilities dataset ${ }^{6}$ (Singer et al. 1972) because of missing and inconsistent reporting of government troop size from UCDP. For rebel troop

\footnotetext{
${ }^{6}$ We use version 5.0 of the National Material Capabilities dataset, which can be retrieved from http: //www . correlatesof war.org/data-sets/national-material-capabilities.
} 
size, but also in the COW data, we try to overcome problems with data availability by interpolating missing data points between records.

External support for rebel groups enables rebels to enhance their capabilities to increase the government's costs and the cost ratio, thus prolonging conflicts. In our analysis, we include two dummy variables to account for weapons and logistics support as well as direct troop support. This data is provided by the Dangerous Companions dataset (San-Akca 2015, 2016).

A direct measurement of costs that both sides have to cope with is casualties. However, data that allows to distinguish which side fatalities can be attributed to is only available for a smaller part of our observation period. We thus use the total number of deaths per conflict/dyad per day to operationalize the total cost $k$. It is essential to calculate the number of casualties per day, as the dependent variable, conflict duration, is also measured per day-although the data are reported per conflict-year, it is necessary to distinguish between two conflicts with the same reported casualties, where one only lasts three days in this year and the other one is active the whole year. To obtain a larger temporal scope, we use data from the UCDP Battle-related Deaths dataset (Pettersson and Öberg 2020) and combine it with data from the PRIO Battle Deaths dataset (Lacina and Gleditsch 2005).

Terrain that is difficult to operate militarily in might increase the relative costs of fighting for the government. We operationalize this as mountainous terrain, using geographic elevation and slope data from the United Nations Environment Programme World Conservation Monitoring Centre UNEP-WCMC (2002). With this data, we are able to compute a mountains index for each conflict site in every year, as is recorded by the PRIO Conflict Site dataset (Buhaug and Gates 2002) and the UCDP Georeferenced Events dataset (Pettersson and Öberg 2020; Sundberg and Melander 2013). For the size of the population, GDP per capita, and GDP growth, we use data from the Maddison Project (Bolt et al. 2018). As is standard in the literature, we use population and GDP per capita in logarithmic form. To capture whether a group might use terrorist tactics, which are hypothesized to increase the relative costs of the government side, we include a dummy variable that indicates whether the Global Terrorism Database also records a rebel group as a terrorist group. For this attribution, we use the TORG crosswalk dataset (Cousins 2014).

As democracies might value the costs of fighting higher (Stam 1996; Filson and Werner 2004), we include a dummy variable for countries with a Polity IV score of 6 and higher (Marshall et al. 2016). Data from the Ethnic Power Relations dataset (Vogt et al. 2015) is used to indicate whether a group is politically excluded. Addi- 
tionally, we control whether the conflict is fought over government or over territory, as coded by UCDP (Harbom et al. 2008; Pettersson and Öberg 2020), for the Cold War period (cf. Kalyvas and Balcells 2010), and, in alternative specifications, for military expenditure as a potential proxy for the government's conflict costs, using data from SIPRI's Military Expenditure Database ${ }^{7}$ imputed with COW's National Material Capabilities data.

\subsection{The instrumental variable survival model}

\subsubsection{Aalen's additive hazards model}

Standard survival models would not be able to rule out that results are affected by the endogenous demand for major weapons imports. In theory, one would expect a forward-looking government to import major weapons when it predicts a longlasting involvement in a conflict. Since transfers of major weapons can take extended time from an order agreement to delivery, governments have to plan ahead, making their import decisions dependent on expected conflict dynamics and duration.

Whenever the effect of an independent variable is presumably endogenous to the dependent variable, an established method to achieve estimates of true causal effects are instrumental variables models (Angrist and Pischke 2009). Regarding the wide use of the Cox model as quasi-standard in the Political Science literature, it would be the obvious path to implement an instrumental variable Cox model. However, the non-collapsibility of the Cox model leads the standard two-stage estimation to give inconsistent estimates (Martinussen and Vansteelandt 2013; Lergenmuller 2017). Consistent Cox IV estimators do exist, but are only suitable to limited domains of application (see e.g. Martínez-Camblor et al. (2019), for binary IVs Wang et al. (2018), for additive confounding MacKenzie et al. (2014), for rare outcomes Lergenmuller (2017), for time-constant covariates Sjolander and Martinussen (2019) $)^{8}$.

$\mathrm{Li}$ et al. (2015) therefore propose to use instead the Aalen additive hazards model for implementing an instrumental variable approach and present an estimator for the specific case of the Lin-Yang additive model that only includes time-constant coefficients. Martinussen et al. (2017) develop an estimator for the standard Aalen model with instrumentation for covariates with time-constant effects. Advancing on these results, Tchetgen et al. (2015) and Lergenmuller (2017) show that the two-stage in-

\footnotetext{
${ }^{7}$ Data of the SIPRI Military Expenditure Database can be retrieved at https://www.sipri.org/ databases/milex.

${ }^{8}$ Martinussen et al. (2019) develop a more general Cox IV estimator, which we also currently experiment with.
} 
strumental variable estimator is a consistent estimator for an endogenous variable's effect in the Aalen additive hazards model.

In contrast to the Cox model, the Aalen additive hazards model has no history of wider usage in Political science. However, it is a commonly used model in Biology and Health statistics since it incorporates some advantages over the Cox model. The covariates' influence is not represented in proportion to the baseline hazard, as is the case in the Cox model, but as an additive (hence the name) contribution to the hazard. The functional form of the hazard $h_{i}(t)$ is specified as

$$
h_{i}(t)=h_{0}(t)+\boldsymbol{\beta}^{\prime} \boldsymbol{X}_{\boldsymbol{i}}(t),
$$

where $h_{0}(t)$ is the baseline hazard, $\boldsymbol{\beta}$ is the vector of coefficients, and $\boldsymbol{X}_{\boldsymbol{i}}(t)$ is the vector of the covariates' values of conflict dyad $i$. Due to this functional form of the hazard, the baseline hazard is a parameter that has to be estimated. Since tests for time-invariant effects of our variables of interest do not reject the hypothesis of the coefficients not varying over time, all coefficients are estimated as constant (cf Ruhe 2018).

\subsubsection{Implementing a two-stage instrumental variable model}

In a two-step instrumental variable survival model (Tchetgen et al. 2015; Lergenmuller 2017), the first stage uses OLS to regress the endogenous variables on the exogenous regressors and the instruments. The predicted values of the first stage regressions are then in the second stage used in the Aalen survival model, instead of the endogenous covariates. In our analyses, the vector of endogenous covariates $\boldsymbol{Y}_{\boldsymbol{i}}$ consists of the arms imports variable as well as the interaction term of arms imports and distance. The vector of instruments $Z_{i}$ comprises the arms imports unrelated to civil conflict and their interaction with distance.

The first stage equation is then

$$
Y_{i}=\gamma^{\prime} X_{i}+\delta^{\prime} Z_{i}
$$

where $\gamma$ and $\delta$ are vectors of the exogenous covariates' and the instruments' regression coefficients, respectively. This equation is estimated by standard OLS to obtain the estimated coefficients $\hat{\gamma}$ and $\hat{\delta}$, which are then used to predict the values of the endogenous covariates:

$$
\hat{\boldsymbol{Y}}_{i}=\hat{\gamma} \boldsymbol{X}_{i}+\hat{\boldsymbol{\delta}} Z_{i}
$$


In the second stage, the predicted values $\hat{\boldsymbol{Y}}_{\boldsymbol{i}}$-instead of the observed values $\boldsymbol{Y}_{\boldsymbol{i}}$ - enter the Aalen model equation as covariates:

$$
h_{i}(t)=h_{0}(t)+\boldsymbol{\theta} \hat{\boldsymbol{Y}}_{\boldsymbol{i}}(t)+\boldsymbol{\beta}^{\prime} \boldsymbol{X}_{\boldsymbol{i}}(t)
$$

where $\boldsymbol{\theta}$ is the endogenous variables' and $\boldsymbol{\beta}$ the exogenous covariates' vector of coefficients, respectively.

As with the standard Two-Stage-Least-Squares estimators, standard errors of the second stage's coefficients might need correction, as the uncertainty in estimating the first stage has to be accounted for. Simulations show that with the timereg: : aalen function, default standard errors only slightly underestimate the true uncertainty of the IV estimates, enabling us to draw valid conclusions about statistical significance in the two-stage Aalen IV model (Lergenmuller 2017). Additionally, we calculated standard errors by bootstrapping, but the results do not differ substantially.

\subsubsection{Instruments}

To be able to apply this instrumental variable approach, we need a valid instrument, i.e. an instrument that is a) related to the instrumented variable and b) exogenous to the duration of intrastate conflict. For instrumenting arms imports of the government, we propose to use the arms imports of hostile states as an instrument. Pamp and Mehltretter (2019) find that imports of major weapons are triggered by the perceived global security environment, as is manifest in the arms imports' of a state's enemies. The arms races logic found for military expenditures (Nordhaus et al. 2012) thus also applies to the arms trade. Therefore, hostile imports of major weapons are a relevant instrument.

At the same time, MCW imports of hostile states are also a valid instrument, because they do not affect the duration of intrastate conflicts by themselves if the hostile importer is not involved in the conflict. If it were involved, imports could be channeled to the rebel group, potentially directly impacting conflict duration. Therefore, we exclude importing countries involved in a conflict in the focal country when computing the total imports of hostile countries. Another potential impact of a hostile state's imports on a focal country's conflicts could be through conflicts in the hostile state: when a hostile country imports arms because of a conflict within its borders, and the duration of the conflict in the focal country is affected due to spillover effects, the validity of the instrument would be violated. However, we find that the number of conflicts in the geographic environment does not impact conflict duration, reject- 
Table 2: First stage results

\begin{tabular}{|c|c|c|c|c|c|c|}
\hline & $\begin{array}{l}\text { MCW imports (lagged) } \\
\text { (1) }\end{array}$ & $\begin{array}{l}\text { Interaction } \\
\quad(2) \\
\end{array}$ & $\begin{array}{c}\text { MCW imports (3 yr. avg.) } \\
\text { (3) }\end{array}$ & $\begin{array}{l}\text { Interaction } \\
\quad(4) \\
\end{array}$ & $\begin{array}{l}\text { MCW imports (5 yr. avg.) } \\
\text { (5) }\end{array}$ & $\begin{array}{l}\text { Interaction } \\
\text { (6) }\end{array}$ \\
\hline log(hostile MCW imports), lagged & $\begin{array}{c}1.063^{* * *} \\
(0.205)\end{array}$ & & & & & \\
\hline instrument $\times$ distance interaction & & $\begin{array}{c}0.933^{* * *} \\
(0.202)\end{array}$ & & $\begin{array}{c}1.244^{* * *} \\
(0.017)\end{array}$ & & $\begin{array}{c}1.549^{* * *} \\
(0.147)\end{array}$ \\
\hline log(hostile MCW imports), 3 yr. avg. & & & $\begin{array}{c}1.239 * * * \\
(0.017)\end{array}$ & & & \\
\hline log(hostile MCW imports), 5 yr. avg. & & & & & $\begin{array}{c}1.663^{* * *} \\
(0.148)\end{array}$ & \\
\hline $\log$ (Distance) & $\begin{array}{c}0.297 * * * \\
(0.077)\end{array}$ & $\begin{array}{l}3.407^{* *} \\
(1.651)\end{array}$ & $\begin{array}{l}0.050 \\
(0.031)\end{array}$ & $\begin{array}{c}1.609^{* * *} \\
(0.401)\end{array}$ & $\begin{array}{c}0.166^{* * *} \\
(0.057)\end{array}$ & $\begin{array}{l}-1.575 \\
(1.222)\end{array}$ \\
\hline $\log$ (Troop ratio) & $\begin{array}{l}0.139 * * \\
(0.058)\end{array}$ & $\begin{array}{c}1.933^{* * *} \\
(0.727)\end{array}$ & $\begin{array}{c}-0.101^{* * *} \\
(0.024)\end{array}$ & $\begin{array}{c}-1.369 * * * \\
(0.296)\end{array}$ & $\begin{array}{l}0.110^{* *} \\
(0.043)\end{array}$ & $\begin{array}{c}1.613^{* * *} \\
(0.551)\end{array}$ \\
\hline External support (weapons) & $\begin{array}{c}0.275 \\
(0.174)\end{array}$ & $\begin{array}{l}3.932^{*} \\
(2.201)\end{array}$ & $\begin{array}{l}-0.143^{* *} \\
(0.071)\end{array}$ & $\begin{array}{l}-1.809^{* *} \\
(0.894)\end{array}$ & $\begin{array}{c}0.376^{* * *} \\
(0.131)\end{array}$ & $\begin{array}{c}5.168^{* * *} \\
(1.660)\end{array}$ \\
\hline External support (troops) & $\begin{array}{c}1.487 * * * \\
(0.346)\end{array}$ & $\begin{array}{c}18.319 * * * \\
(4.373)\end{array}$ & $\begin{array}{l}0.167 \\
(0.141)\end{array}$ & $\begin{array}{l}2.070 \\
(1.773)\end{array}$ & $\begin{array}{c}1.181^{* * *} \\
(0.259)\end{array}$ & $\begin{array}{c}14.119^{* * *} \\
(3.284)\end{array}$ \\
\hline Battle-related deaths per day_thds & $\begin{array}{l}0.328^{* *} \\
(0.163)\end{array}$ & $\begin{array}{l}4.013^{*} \\
(2.056)\end{array}$ & $\begin{array}{l}-0.066 \\
(0.064)\end{array}$ & $\begin{array}{l}-0.848 \\
(0.805)\end{array}$ & $\begin{array}{c}0.066 \\
(0.119)\end{array}$ & $\begin{array}{c}0.927 \\
(1.506)\end{array}$ \\
\hline Conflict over government (vs. territory) & $\begin{array}{c}0.370 \\
(0.241)\end{array}$ & $\begin{array}{l}5.371^{*} \\
(3.045)\end{array}$ & $\begin{array}{c}0.525^{* * *} \\
(0.098)\end{array}$ & $\begin{array}{c}6.235 * * * \\
(1.232)\end{array}$ & $\begin{array}{l}0.303^{*} \\
(0.181)\end{array}$ & $\begin{array}{l}4.075^{*} \\
(2.300)\end{array}$ \\
\hline Group is excluded & $\begin{array}{l}-0.450^{* *} \\
(0.223)\end{array}$ & $\begin{array}{l}-4.950^{*} \\
(2.818)\end{array}$ & $\begin{array}{l}0.158^{*} \\
(0.091)\end{array}$ & $\begin{array}{l}2.202^{*} \\
(1.144)\end{array}$ & $\begin{array}{l}-0.412^{* *} \\
(0.168)\end{array}$ & $\begin{array}{l}-4.797^{* *} \\
(2.130)\end{array}$ \\
\hline Democracy dummy & $\begin{array}{l}-0.191 \\
(0.232)\end{array}$ & $\begin{array}{l}-2.201 \\
(2.936)\end{array}$ & $\begin{array}{c}0.322^{* * *} \\
(0.094)\end{array}$ & $\begin{array}{c}4.455^{* * *} \\
(1.181)\end{array}$ & $\begin{array}{c}0.072 \\
(0.174)\end{array}$ & $\begin{array}{l}1.610 \\
(2.205)\end{array}$ \\
\hline GDP p.c. growth & $\begin{array}{l}2.085^{*} \\
(1.082)\end{array}$ & $\begin{array}{l}16.286 \\
(13.654)\end{array}$ & $\begin{array}{l}1.050^{* *} \\
(0.425)\end{array}$ & $\begin{array}{c}11.882^{* *} \\
(5.345)\end{array}$ & $\begin{array}{l}-1.344^{*} \\
(0.787)\end{array}$ & $\begin{array}{l}-21.060^{* *} \\
(9.990)\end{array}$ \\
\hline $\log ($ GDP p.c. $)$ & $\begin{array}{c}1.086^{* * *} \\
(0.108)\end{array}$ & $\begin{array}{c}13.557 * * * \\
(1.369)\end{array}$ & $\begin{array}{l}0.015 \\
(0.045)\end{array}$ & $\begin{array}{l}-0.123 \\
(0.564)\end{array}$ & $\begin{array}{c}0.920^{* * *} \\
(0.081)\end{array}$ & $\begin{array}{c}11.429^{* * *} \\
(1.024)\end{array}$ \\
\hline $\log$ (Population) & $\begin{array}{c}0.915^{* * *} \\
(0.092)\end{array}$ & $\begin{array}{c}12.553^{* * *} \\
(1.160)\end{array}$ & $\begin{array}{c}0.207^{* * *} \\
(0.038)\end{array}$ & $\begin{array}{c}2.514^{* * *} \\
(0.481)\end{array}$ & $\begin{array}{c}1.071^{* * *} \\
(0.070)\end{array}$ & $\begin{array}{c}14.022^{* * *} \\
(0.882)\end{array}$ \\
\hline Group is terrorist group & $\begin{array}{c}0.123 \\
(0.185)\end{array}$ & $\begin{array}{l}1.229 \\
(2.338)\end{array}$ & $\begin{array}{c}0.041 \\
(0.075)\end{array}$ & $\begin{array}{l}0.551 \\
(0.946)\end{array}$ & $\begin{array}{c}0.091 \\
(0.139)\end{array}$ & $\begin{array}{c}0.769 \\
(1.765)\end{array}$ \\
\hline Mountainous terrain & $\begin{array}{c}0.648 * * * \\
(0.131)\end{array}$ & $\begin{array}{c}7.578 * * * \\
(1.656)\end{array}$ & $\begin{array}{l}-0.009 \\
(0.054)\end{array}$ & $\begin{array}{l}-0.352 \\
(0.679)\end{array}$ & $\begin{array}{c}0.505 * * * \\
(0.099)\end{array}$ & $\begin{array}{c}6.207 * * * \\
(1.257)\end{array}$ \\
\hline Cold War dummy & $\begin{array}{c}1.413 * * * \\
(0.193)\end{array}$ & $\begin{array}{c}17.820^{* * *} \\
(2.441)\end{array}$ & $\begin{array}{c}0.909 * * * \\
(0.076)\end{array}$ & $\begin{array}{c}11.124 * * * \\
(0.961)\end{array}$ & $\begin{array}{c}1.449^{* * *} \\
(0.143)\end{array}$ & $\begin{array}{c}18.152^{* * *} \\
(1.819)\end{array}$ \\
\hline Constant & $\begin{array}{c}-33.384^{* * *} \\
(2.220)\end{array}$ & $\begin{array}{c}-420.784^{* * *} \\
(25.570)\end{array}$ & $\begin{array}{c}-3.359 * * * \\
(0.875)\end{array}$ & $\begin{array}{c}-48.345^{* * *} \\
(11.431)\end{array}$ & $\begin{array}{c}-35.526^{* * *} \\
(1.676)\end{array}$ & $\begin{array}{c}-399.058^{* * *} \\
(19.199)\end{array}$ \\
\hline $\begin{array}{l}\text { Observations } \\
\mathrm{R}^{2}\end{array}$ & $\begin{array}{l}1,616 \\
0.298\end{array}$ & $\begin{array}{l}1,616 \\
0.369\end{array}$ & $\begin{array}{l}1,619 \\
0.851\end{array}$ & $\begin{array}{l}1,619 \\
0.872\end{array}$ & $\begin{array}{l}1,619 \\
0.442\end{array}$ & $\begin{array}{l}1,619 \\
0.517\end{array}$ \\
\hline Adjusted $R^{2}$ & 0.291 & 0.363 & 0.850 & 0.871 & 0.437 & 0.513 \\
\hline F Statistic & $45.187^{* * *}$ & $62.460^{* * *}$ & $611.611^{* * *}$ & $727.241^{* * *}$ & $84.605^{* * *}$ & $114.570^{* * *}$ \\
\hline
\end{tabular}


ing the hypothesis of a direct effect of hostile states' imports. Thus, this instrument allows us to correctly identify the causal effects of arms imports on conflict duration.

To generate the instrumental variable, we use the sum of all imports of hostile states in a given year (or their 3- or 5-year average to match the operationalization of arms imports of the focal country). Whether a country is hostile is determined by how different they vote in the UN general assembly, as computed in the "ideal points" measure from Bailey et al. (2017). Since there is no natural threshold when a country should be counted as hostile, we propose to use a one-standard-deviation difference. We weigh the hostile country's imports both by the absolute difference in ideal points and by geographic distance, as closer countries are more significant threats to a country's external security. For instrumenting the interaction term of arms imports and distance, the interaction of the instrument for arms imports, i.e. arms unrelated to civil conflict, and distance is used.

\section{Table 2 to appear here}

While the instrumental variables' exogeneity is untestable, we can prove relevance empirically. Table 2 shows the results of the OLS regressions at the first stage of the IV model estimation (see section 4.3.2 for details). Imports of MCW and their interaction with distance are the respective dependent variable. As independent variables, the instrument and the instrument's interaction with distance, respectively, and all control variables of the second stage are included. For both models, we find that hostile MCW imports are significantly positively associated with a focal country's imports, with F-statistics indicating strong relevance.

\section{Empirical results}

Table 3 to appear here

Table 3 presents the results of models with different specifications of arms imports as lagged (models 1 and 2), 3-year averaged (models 3 and 4), and 5-year averaged variables (models 5 and 6). While odd-numbered models use the standard Aalen additive hazards estimator, even-numbered models employ the two-stage instrumental variable Aalen estimator. Note that coefficients in these survival models represent the variables' effect on the hazard of the termination event, meaning that a negative coefficient implies a lower termination risk and thus a conflict-prolonging effect of a 
Table 3: Main results (Aalen estimation)

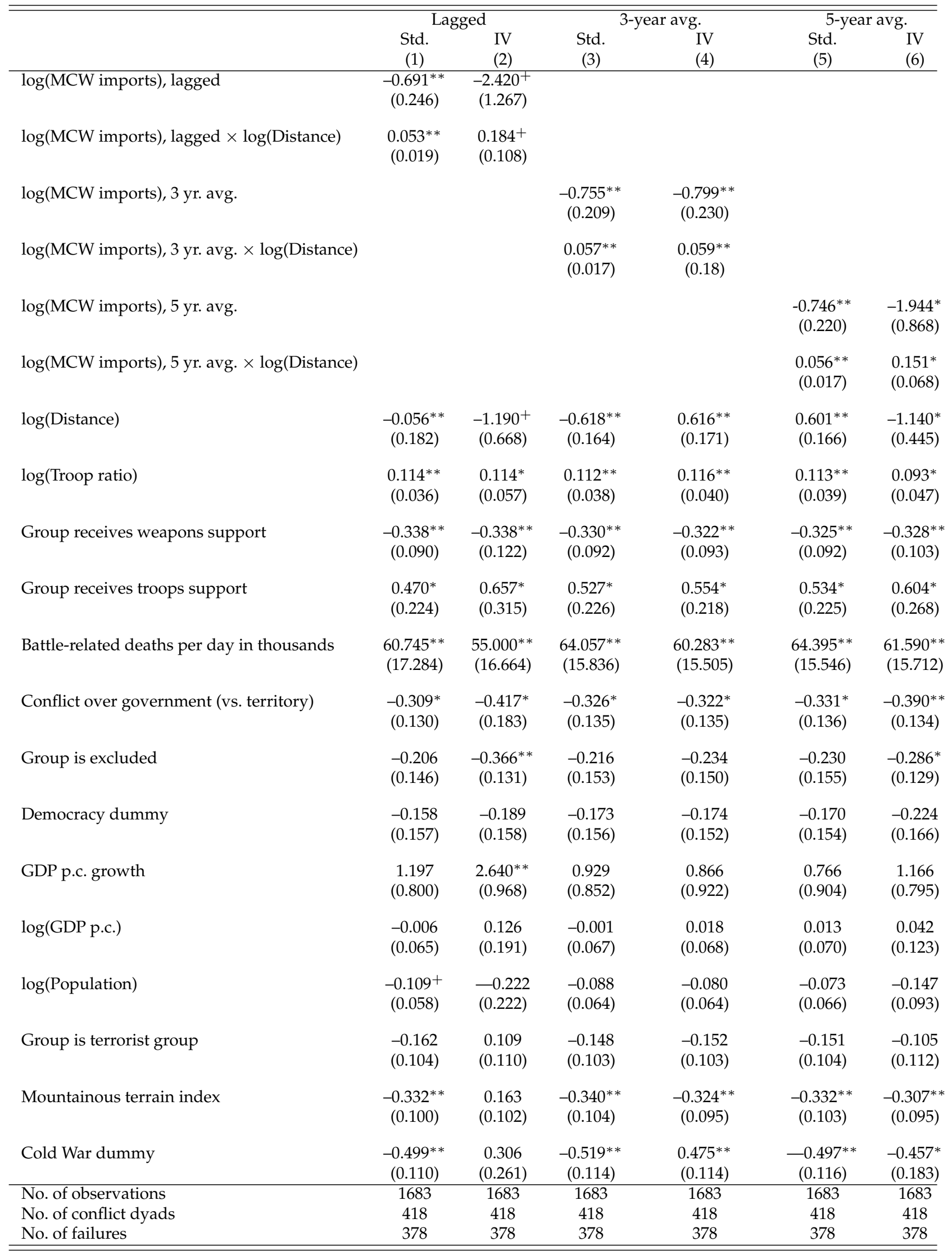

Note: ${ }^{*}\left(+,{ }^{* *}\right)$ indicates $p<.05(.1, .01)$. All coefficients and standard errors are multiplied by $10^{-3}$. 
Figure 2: Imports-distance combinations and direction of duration effect

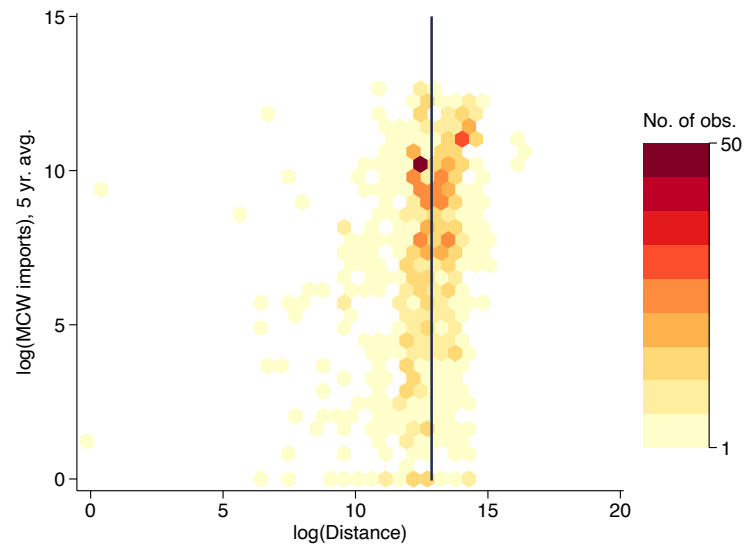

The plot shows the frequency of arms imports-distance combinations in the analyzed data. The vertical line indicates the distance above which the total effect of arms imports is positive, i.e. duration-reducing.

variable.

Over all models, the arms imports variables exhibit ceteris paribus a negative effect on the termination hazard. The coefficient of the interaction is positive in all models, indicating an increasingly conflict-shortening effect of arms imports at longer distances. Distance by itself clearly increases conflict duration in all models. These effects hold for all models, both standard and instrumented. Effects of arms imports on the duration of conflicts are thus validated to be causal.

Interpreting the total effect of arms imports needs caution, as it can only be retrieved by combining the arms imports variable's and the interaction term's effects, with the latter depending on distance. As these effects have different signs, there exists a specific distance at which they cancel out. Below this threshold distance, arms imports prolong conflicts, while they reduce duration above it. Regarding model 6, for instance, arms imports have a shortening effect for all distances above $390 \mathrm{~km}$.

Figure 2 to appear here

Figure 2 illustrates that for $45 \%$ of observations in our sample, arms imports lead to shorter duration, as they lie to the right of the vertical line depicting the threshold distance. Note that we only have a very limited number of observations with small distances, leading to weak support for predictions regarding arms' effects at low distances. 
Figure 3: Distribution of changes in survival predictions for hypothetical increases in MCW imports

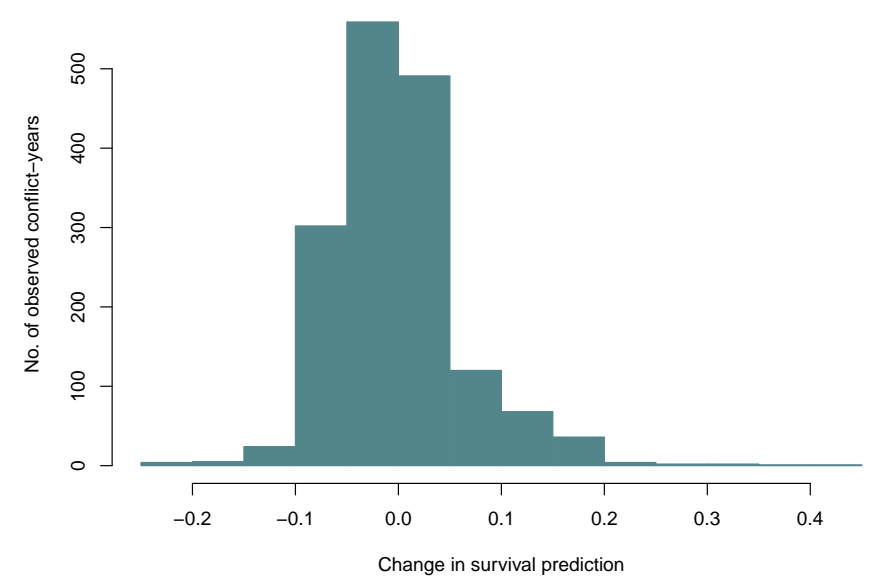

The plot shows the distribution of changes in survival predictions, when MCW imports were increased by a hypothetical $25 \%$ in comparison to the observed values.

\section{Figure 3 to appear here}

An additional advantage of the Aalen additive hazards model to the standard Cox model is the possibility to compute predictions due to the Aalen model, in contrast to the Cox model, estimating the baseline hazard. We are thus able to illustrate the effects of arms imports on the estimated survival rate. Figure 3 shows the distribution of changes in the predicted survival rates when arms imports were hypothetically increased by $25 \%$. Note that the survival rates were calculated for the median observed duration. Depending on the distance, we find both duration-reducing and -increasing effects of this increase in arms imports. For an exemplary distance of $500 \mathrm{~km}$ at median values of all other variables, a one-standard-deviation increase in $\mathrm{MCW}$ imports reduces the predicted survival rate at the median duration by .03 .

Comparing the empirical results to our theoretical expectations, they provide evidence for hypothesis 6 predicting an increasingly duration-reducing effect of governmental military build-ups at larger distances. That this effect only exists at larger distances can also be explained by our theory: procurement of MCW raises the government's ability to inflict costs on the rebel group in particular for conflicts in such remote areas. At the same time, the government has to bear the costs of acquisition and maintenance for these major weapons independent of the conflict circum- 
stances. Thus, arms imports might render the cost ratio more favorable to the rebels in conflicts at small distances and more favorable to the government in conflicts at larger distances. Therefore, armament exhibits a conflict-prolonging effect at small distances and a conflict-shortening effect at larger distances.

Most of the literature has found either a conflict-prolonging or no significant effect of government strength relative to rebel strength. In contrast, in our analysis, the positive coefficient of the ratio of government troops to rebel troops indicates that conflicts are indeed shorter the more favorable this ratio turns out for the government. This corroborates hypothesis 1 on the duration-reducing effect of government capabilities, as derived from the war-of-attrition framework, but clearly contradicts the results from Cunningham et al. (2009) and Buhaug et al. (2009) obtained with data from the Non-State Actors dataset.

Evidence for hypothesis 2 predicting increased rebel capabilities to prolong conflicts is mixed regarding the military capabilities of the rebel side. External support by weapons transfers prolongs conflicts as predicted, but direct troop support affects conflict duration negatively, corroborating Sawyer et al. (2017) with different data on external support. Making sense of this result within the war-of-attrition framework, this finding might indicate that third-party troops can shift the distribution of military capabilities substantially, so that the government would not be the stronger side anymore. Then, increasing the capabilities of the stronger, i.e. rebel in this case, side would be expected to lead to shorter conflict durations (cf. Balch-Lindsay et al. 2008). Mountainous terrain, favoring the rebel side, exhibits conflict-prolonging effects, in line with the predictions from hypothesis 2 and corroborating the theoretical considerations in Fearon and Laitin (2003).

Higher total costs are expected to lead to shorter conflicts. Corroborating the respective hypothesis 3 , the number of battle-related deaths per day exhibit a clear duration-reducing impact, meaning more intense conflicts end earlier. Notably, we can thereby substantiate similar theoretical considerations from Brandt et al. (2008), although they themselves were not able to corroborate their hypothesis empirically. In contrast to casualties, costs in terms of economic growth are not found to play a role for conflict duration. The same is the case for democracy, contradicting hypothesis 4 that democracies value costs higher. However, higher valuations of winning for excluded groups, as stated in hypothesis 5 , are consistent with findings that excluded groups fight longer conflicts. Additionally, conflicts that are fought over government last longer than conflicts over territory. 


\section{Validating robustness}

To corroborate the robustness of the results presented above, we provide results with differing estimation methods and specifications. Since the semi-parametric Cox proportional hazards model (Cox 1972) is the standard workhorse model in Political Science analyses, table A1 in the appendix reproduces the results from the Aalen estimations in table 3, confirming sign and statistical significance of the variables of interest (see appendix for further details).

\section{Table 4 to appear here}

To reflect on additional, theoretically motivated issues, table 4 presents six models specified with different sets of covariates. Model 1 examines whether the theoretically derived effects of asymmetry in military capabilities can be found in the measure of troop ratio. In contrast to the other variables, we have data available to capture the military capabilities of the government and rebel side in relative terms: the troop ratio is an accurate measure of relative capabilities. It should thus exhibit the asymmetric effects as found in the war-of-attrition duration framework. However, when including the squared troop ratio, the coefficients of both the regular and squared variables lose statistical significance. Nevertheless, this is most likely a consequence of the very limited number of cases where the overall cost ratio favors the rebel side. Arms imports' effects are nonetheless robust to implementing a non-linear effect of the troop ratio.

As argued in section 3.4, arms of different types might provide specific advantages in different conflict environments at different distances. Thus, models 2 and 3 review hypothesis 3 for subcategories of arms imports, i.e. for imports of ground equipment like tanks, armored vehicles, and artillery and imports of air weapon systems like aircraft, helicopters, and missiles, respectively. Results differ only slightly, corroborating the prediction of hypothesis 3-that imported arms are effective tools to end conflicts at larger distances-for both types of ground and air imports separately as well.

Models 4 and 5 include additional measures of rebel and government capabilities, respectively. Following Moore (2012), model 4 uses SIPRI data on major weapons imports of rebel groups. Their effect is not statistically significant-most likely, this is not a substantial finding on the (non-)impact of rebels' arms endowments, but is a result of only very limited information on the arms trade to rebels, as is comprised in the SIPRI data. In model 5, we include military expenditures as a direct financial 
Table 4: Robustness results

\begin{tabular}{|c|c|c|c|c|c|c|}
\hline \multirow{3}{*}{$\log ($ Distance $)$} & \multirow{3}{*}{$\begin{array}{c}\text { Sq. troop ratio } \\
(1) \\
-0.193^{* *} \\
(0.032)\end{array}$} & \multicolumn{2}{|c|}{ Arms types split } & \multirow{2}{*}{$\begin{array}{c}\text { Rebel MCW } \\
\text { (4) }\end{array}$} & \multirow{2}{*}{$\begin{array}{l}\text { Mil. exp. } \\
\text { (5) }\end{array}$} & \multirow{2}{*}{$\begin{array}{c}\text { Conflict-level } \\
\text { (6) }\end{array}$} \\
\hline & & (2) & (3) & & & \\
\hline & & & $\begin{array}{c}-0.195^{* *} \\
(0.031)\end{array}$ & $\begin{array}{c}-0.196^{* *} \\
(0.032)\end{array}$ & $\begin{array}{c}-0.177^{* *} \\
(0.035)\end{array}$ & $\begin{array}{c}-0.206^{* *} \\
(0.035)\end{array}$ \\
\hline $\log (\mathrm{MCW}$ imports $)$, lagged $\times \log ($ Distance $)$ & $\begin{array}{l}0.013^{*} \\
(0.006)\end{array}$ & & & $\begin{array}{l}0.014^{*} \\
(0.006)\end{array}$ & $\begin{array}{l}0.016^{*} \\
(0.006)\end{array}$ & $\begin{array}{c}0.015^{* *} \\
(0.006)\end{array}$ \\
\hline $\log ($ Ground imports $)$, lagged $\times \log ($ Distance $)$ & & $\begin{array}{c}0.059 * * \\
(0.022)\end{array}$ & & & & \\
\hline $\log$ (Air imports), lagged & & & $\begin{array}{c}-0.426^{* *} \\
(0.159)\end{array}$ & & & \\
\hline $\log$ (Air imports), lagged $\times \log ($ Distance $)$ & & & $\begin{array}{l}0.032^{*} \\
(0.013)\end{array}$ & & & \\
\hline $\log$ (Troop ratio) & $\begin{array}{c}0.014 \\
(0.131)\end{array}$ & $\begin{array}{c}0.114^{* *} \\
(0.037)\end{array}$ & $\begin{array}{c}0.120^{* *} \\
(0.037)\end{array}$ & $\begin{array}{c}0.118^{* *} \\
(0.036)\end{array}$ & $\begin{array}{c}0.113^{* *} \\
(0.038)\end{array}$ & $\begin{array}{c}0.201^{* *} \\
(0.045)\end{array}$ \\
\hline $\log$ (Troop ratio), squared & $\begin{array}{c}0.006 \\
(0.008)\end{array}$ & & & & & \\
\hline $\log (\mathrm{MCW}$ imports of rebel group), $5 \mathrm{yr}$. avg. & & & & $\begin{array}{c}0.158 \\
(0.171)\end{array}$ & & \\
\hline $\log$ (Military expenditures) & & & & & $\begin{array}{l}-0.079 \\
(0.048)\end{array}$ & \\
\hline Group receives weapons support & $\begin{array}{c}-0.374^{* *} \\
(0.122)\end{array}$ & $\begin{array}{c}-0.401^{* *} \\
(0.123)\end{array}$ & $\begin{array}{c}-0.368^{* *} \\
(0.123)\end{array}$ & $\begin{array}{c}-0.384^{* *} \\
(0.124)\end{array}$ & $\begin{array}{c}-0.352^{*} \\
(0.141)\end{array}$ & $\begin{array}{c}-0.411^{*} \\
(0.160)\end{array}$ \\
\hline Group receives troops support & $\begin{array}{c}0.527^{* *} \\
(0.152)\end{array}$ & $\begin{array}{c}0.554^{* *} \\
(0.157)\end{array}$ & $\begin{array}{c}0.564^{* *} \\
(0.156)\end{array}$ & $\begin{array}{c}0.541^{* *} \\
(0.152)\end{array}$ & $\begin{array}{c}0.580^{* *} \\
(0.162)\end{array}$ & $\begin{array}{c}0.507^{+} \\
(0.266)\end{array}$ \\
\hline Battle-related deaths per day in thousands & $\begin{array}{c}0.198^{* *} \\
(0.024)\end{array}$ & $\begin{array}{c}0.203^{* *} \\
(0.023)\end{array}$ & $\begin{array}{c}0.202^{* *} \\
(0.024)\end{array}$ & $\begin{array}{c}0.198^{* *} \\
(0.023)\end{array}$ & $\begin{array}{c}0.982 * * \\
(0.215)\end{array}$ & $\begin{array}{c}0.458^{* *} \\
(0.172)\end{array}$ \\
\hline Group is excluded & $\begin{array}{c}-0.278^{*} \\
(0.120)\end{array}$ & $\begin{array}{c}-0.303^{*} \\
(0.124)\end{array}$ & $\begin{array}{r}-0.276^{*} \\
(0.119)\end{array}$ & $\begin{array}{c}-0.271^{*} \\
(0.123)\end{array}$ & $\begin{array}{c}-0.374^{* *} \\
(0.142)\end{array}$ & $\begin{array}{c}-0.384^{*} \\
(0.150)\end{array}$ \\
\hline Democracy dummy & $\begin{array}{l}-0.241 \\
(0.171)\end{array}$ & $\begin{array}{l}-0.283 \\
(0.177)\end{array}$ & $\begin{array}{l}-0.217 \\
(0.168)\end{array}$ & $\begin{array}{l}-0.225 \\
(0.170)\end{array}$ & $\begin{array}{l}-0.201 \\
(0.189)\end{array}$ & $\begin{array}{c}-0.377^{+} \\
(0.213)\end{array}$ \\
\hline GDP p.c. growth & $\begin{array}{c}0.333 \\
(0.567)\end{array}$ & $\begin{array}{c}0.333 \\
(0.573)\end{array}$ & $\begin{array}{c}0.262 \\
(0.557)\end{array}$ & $\begin{array}{c}0.311 \\
(0.555)\end{array}$ & $\begin{array}{l}1.338^{+} \\
(0.812)\end{array}$ & $\begin{array}{l}-0.194 \\
(0.577)\end{array}$ \\
\hline $\log$ (GDP p.c.) & $\begin{array}{l}-0.038 \\
(0.064)\end{array}$ & $\begin{array}{l}-0.029 \\
(0.066)\end{array}$ & $\begin{array}{l}-0.036 \\
(0.066)\end{array}$ & $\begin{array}{l}-0.043 \\
(0.065)\end{array}$ & $\begin{array}{c}0.023 \\
(0.086)\end{array}$ & $\begin{array}{l}-0.020 \\
(0.070)\end{array}$ \\
\hline $\log$ (Population) & $\begin{array}{c}-0.115^{*} \\
(0.056)\end{array}$ & $\begin{array}{r}-0.110^{+} \\
(0.060)\end{array}$ & $\begin{array}{c}-0.110^{+} \\
(0.057)\end{array}$ & $\begin{array}{c}-0.109^{+} \\
(0.057)\end{array}$ & $\begin{array}{c}-0.094^{+} \\
(0.054)\end{array}$ & $\begin{array}{c}-0.180^{* *} \\
(0.066)\end{array}$ \\
\hline Group is terrorist group & $\begin{array}{c}-0.368^{* *} \\
(0.123)\end{array}$ & $\begin{array}{c}-0.388^{* *} \\
(0.124)\end{array}$ & $\begin{array}{c}-0.372^{* *} \\
(0.122)\end{array}$ & $\begin{array}{c}-0.373^{* *} \\
(0.123)\end{array}$ & $\begin{array}{c}-0.399^{* *} \\
(0.125)\end{array}$ & $\begin{array}{c}-0.542^{* *} \\
(0.151)\end{array}$ \\
\hline Mountainous terrain index & $\begin{array}{c}-0.192^{+} \\
(0.110)\end{array}$ & $\begin{array}{c}-0.176^{+} \\
(0.105)\end{array}$ & $\begin{array}{c}-0.190^{+} \\
(0.107)\end{array}$ & $\begin{array}{c}-0.194^{+} \\
(0.110)\end{array}$ & $\begin{array}{l}-0.128 \\
(0.103)\end{array}$ & $\begin{array}{l}-0.067 \\
(0.116)\end{array}$ \\
\hline Cold War dummy & $\begin{array}{c}-0.471^{* *} \\
(0.135)\end{array}$ & $\begin{array}{c}-0.481^{* *} \\
(0.123)\end{array}$ & $\begin{array}{c}-0.476^{* *} \\
(0.129)\end{array}$ & $\begin{array}{c}-0.484^{* *} \\
(0.135)\end{array}$ & $\begin{array}{c}-0.519^{* *} \\
(0.139)\end{array}$ & $\begin{array}{c}-0.602^{* *} \\
(0.168)\end{array}$ \\
\hline $\log ($ Distance $)$ & & $\begin{array}{c}-0.195^{* *} \\
(0.032)\end{array}$ & & & & \\
\hline No. of observations & 1683 & 1669 & 1683 & 1683 & 1380 & 1339 \\
\hline No. of conflict dyads/conflicts (model 6) & 418 & 416 & 418 & 418 & 342 & 257 \\
\hline No. of failures & 378 & 376 & 378 & 378 & 306 & 220 \\
\hline
\end{tabular}

Note: ${ }^{*}\left({ }^{+},{ }^{* *}\right)$ indicates $p<.05(.1, .01)$ 
measure of potential conflict costs. However, they do not exhibit a statistically significant impact on conflict duration, whereas the effect of arms imports does not change substantially.

At last, model 6 shifts the level of analysis-instead of analyzing conflict-dyads, its unit of analysis is the conflict, consisting of one or multiple dyads. Notably, the effects of arms imports are robust to a change of the specification of duration as either duration of a conflict-dyad or of a potentially multi-dyadic conflict.

\section{Conclusion}

In this paper, we find robust results on the impact of governmental armament on the duration of intrastate conflict. In contrast to the whole existing literature, we propose a causal design using an instrumental variable survival approach, based on the Aalen additive hazards model. In our opinion, this is a worthwhile addition to the empirical toolbox of Political Science and should be considered whenever endogeneity is of concern in event history analysis.

As a theoretical contribution, we adapt a war-of-attrition framework from Powell (2017) to show that in intrastate conflicts, where the government usually is the stronger side, enhancing the government's capacities leads to shorter conflicts, while strengthening the rebel side leads to more prolonged conflicts. As military build-ups allow to afflict costs onto adversaries, a government's armament in the form of arms imports forces the rebel side to withdraw earlier from the conflict, reducing its duration. In practice, arms transfers provide effective capabilities to combat rebels and insurgents not only in open battles, but also in guerrilla warfare. Especially in conflicts in remote areas, major weapons allow for the necessary projection of power over larger distances.

It is a widely accepted fact in the literature that weakness of rebels relative to the government prolongs conflicts, but guided by our formal framework, we robustly find the opposite when using rebel troop size from UCDP as a measure for rebel strength. Further investigation seems warranted to clarify whether the different results hinge on differences in data quality of the UCDP and Non-State-Actors data (Cunningham et al. 2013) or if they operationalize rebel strength in diverging but meaningful ways. Nevertheless, our findings regarding the troop ratio are perfectly in line with the theoretical predictions derived from the war-of-attrition framework.

On the whole, we do not assess whether governments fight conflicts for a just cause, but extract general patterns of causality in the relationship between governmental 
armament, the geographical context of the conflict, and its duration. Notably, when governments fight civil wars with rebel groups, they are faced with the decision to shift scarce resources to invest into armament (cf. Powell 1993; Besley and Persson 2011). This usually concerns low- or middle-income countries with high opportunity costs, making military investments a burdensome decision. Furthermore, increased armament might cause conflicts to intensify (Mehrl and Thurner 2020), rendering conflict severity and duration a complex trade-off. How this trade-off depends on the specific circumstances regarding e.g. distance and rebel strength should be investigated in future research. Overall, building up military capacities is arguably not the preferable solution to deal with prolonged conflicts, even though-as we have shown-it might help in the narrow sense of ending some conflicts earlier. 


\section{References}

Angrist, Joshua D. and Jörn-Steffen Pischke (2009). Mostly Harmless Econometrics: An Empiricist's Companion. Princeton, NJ: Princeton University Press.

Bailey, Michael A., Anton Strezhnev, and Erik Voeten (2017). Estimating Dynamic State Preferences from United Nations Voting Data. Journal of Conflict Resolution 61(2), 430-456.

Balcells, Laia and Stathis N. Kalyvas (2014). Does Warfare Matter? Severity, Duration, and Outcomes of Civil Wars. Journal of Conflict Resolution 58(8), 1390-1418.

Balch-Lindsay, Dylan and Andrew J. Enterline (2007). Killing Time: The World Politics of Civil War Duration, 1820-1992. International Studies Quarterly 44(4), 615-642.

Balch-Lindsay, Dylan, Andrew J. Enterline, and Kyle A. Joyce (2008). Third-Party Intervention and the Civil War Process. Journal of Peace Research 45(3), 345-363.

Bennett, D. Scott and Allan C. Stam, III (1996). The Duration of Interstate Wars, 1816-1985. The American Political Science Review 90(2), 239-257.

Besley, Timothy and Torsten Persson (2011). The Logic of Political Violence. Quarterly Journal of Economics 126(3), 1411-1445.

Bolt, Jutta, Robert Inklaar, Herman de Jong, and Jan Luiten van Zanden (2018). Rebasing 'Maddison': New Income Comparisons and the Shape of Long-Run Economic Development. GGDC Research Memorandum 174, 1-67.

Boulding, Kenneth Ewart (1962). Conflict and Defense: A General Theory. New York: Harper and Row.

Brandt, Patrick T., T. David Mason, Mehmet Gurses, Nicolai Petrovsky, and Dagmar Radin (2008). When and How the Fighting Stops: Explaining the Duration and Outcome of Civil Wars. Defence and Peace Economics 19(6), 415-434.

Brzoska, Michael (2004). The Economics of Arms Imports after the End of the Cold War. Defence and Peace Economics 15(2), 111-123.

Buhaug, Halvard (2010). Dude, Where's My Conflict? Conflict Management and Peace Science 27(2), 107-128.

Buhaug, Halvard and Scott Gates (2002). The Geography of Civil War. Journal of Peace Research 39(4), 417-433.

Buhaug, Halvard, Scott Gates, and Päivi Lujala (2009). Geography, Rebel Capability, and the Duration of Civil Conflict. Journal of Conflict Resolution 53(4), 544-569.

Buhaug, Halvard and Päivi Lujala (2005). Accounting for scale: Measuring geography in quantitative studies of civil war. Political Geography 24(4), 399-418.

Butler, Christopher and Scott Gates (2009). Asymmetry, Parity, and (Civil) War: Can International Theories of Power Help Us Understand Civil War? International In- 
teractions 35(3), 330-341.

Caverley, Jonathan D. and Todd S. Sechser (2017). Military Technology and the Duration of Civil Conflict. International Studies Quarterly 61(3), 704-720.

Cederman, Lars-Erik, Halvard Buhaug, and Jan Ketil Rød (2009). Ethno-Nationalist Dyads and Civil War. Journal of Conflict Resolution 53(4), 496-525.

Cederman, Lars-Erik, Kristian Skrede Gleditsch, and Halvard Buhaug (2013). Inequality, Grievances, and Civil War. New York: Cambridge University Press.

Collier, Paul, Anke Hoeffler, and Måns Söderbom (2004). On the Duration of Civil War. Journal of Peace Research 41(3), 253-273.

Corum, James S. and Wray R. Johnson (2003). Airpower in Small Wars. Fighting Insurgents and Terrorists. Lawrance, KS: University Press of Kansas.

Cousins, Ken (2014). The TORG Crosswalk Dataset.

Cox, D. R. (1972). Regression Models and Life-Tables. Journal of the Royal Statistical Society: Series B (Methodological) 34(2), 187-202.

Cunningham, David E. (2010). Blocking resolution: How external states can prolong civil wars. Journal of Peace Research 47(2), 115-127.

Cunningham, David E., Kristian Skrede Gleditsch, and Idean Salehyan (2009). It Takes Two. A Dyadic Analysis of Civil War Duration and Outcome. Journal of Conflict Resolution 53(4), 570-597.

Cunningham, David E., Kristian Skrede Gleditsch, and Idean Salehyan (2013). NonState Actors in Civil Wars: A New Dataset. Conflict Management and Peace Science 30(5), 516-531.

DeRouen, Karl R. and David Sobek (2004). The Dynamics of Civil War Duration and Outcome. Journal of Peace Research 41(3), 303-320.

Dunlap Jr., Charles J. (2008). Making Revolutionary Change: Airpower in COIN Today. Parameters 38(2), 52-66.

Fearon, James D. (2004). Why Do Some Civil Wars Last So Much Longer Than Others? Journal of Peace Research 41(3), 275-301.

Fearon, James D. and David D. Laitin (2003). Ethnicity, Insurgency, and Civil War. The American Political Science Review 97(1), 75-90.

Filson, Darren and Suzanne Werner (2004). Bargaining and Fighting: The Impact of Regime Type on War Onset, Duration, and Outcomes. American Journal of Political Science 48(2), 296-313.

Harbom, Lotta, Erik Melander, and Peter Wallensteen (2008). Dyadic Dimensions of Armed Conflict, 1946-2007. Journal of Peace Research 45(5), 697-710.

Herbst, Jeffrey (2000). War and State in Africa, Volume 14.4. Princeton: Princeton 
University Press.

Hirshleifer, Jack (1988). The Analytics of Continuing Conflict. Synthese 76(2), 201233.

Hirshleifer, Jack (2000). The Macrotechnology of Conflict. Journal of Conflict Resolution 44(6), 773-792.

Holtom, Paul, Mark Bromley, and Verena Simmel (2012). Measuring International Arms Transfers. SIPRI Fact Sheet.

Hultquist, Philip (2013). Power parity and peace? The role of relative power in civil war settlement. Journal of Peace Research 50(5), 623-634.

Johnson, David E. and John Gordon IV (2010). Observations on Recent Trends in Armored Forces. RAND Occasional Paper.

Johnson, Richard A.I. (2017). The Role and Capabilities of Major Weapon Systems Transferred between 1950 and 2010: Empirical Examinations of an Arms Transfer Data Set. Defence and Peace Economics 28(3), 272-297.

Kalyvas, Stathis N. and Laia Balcells (2010). International System and Technologies of Rebellion: How the End of the Cold War Shaped Internal Conflict. American Political Science Review 104(3), 415-429.

Lacina, Bethany and Nils Petter Gleditsch (2005, June). Monitoring Trends in Global Combat: A New Dataset of Battle Deaths. European Journal of Population / Revue européenne de Démographie 21(2-3), 145-166.

Lebacher, Michael, Paul W. Thurner, and Göran Kauermann (2021). Censored regression for modelling small arms trade volumes and its 'Forensic' use for exploring unreported trades. Journal of the Royal Statistical Society: Series C (Applied Statistics) 70(4), 909-933.

Lergenmuller, Simon (2017). Two-stage predictor substitution for time-to-event data. Ph. D. thesis.

Li, Jialiang, Jason Fine, and Alan Brookhart (2015). Instrumental Variable Additive Hazards Models. Biometrics 71(1), 122-130.

Lockyer, Adam (2010). The Dynamics of Warfare in Civil War. Civil Wars 12(1-2), 91-116.

Lyall, Jason and Isaiah Wilson (2009). Rage Against the Machines: Explaining Outcomes in Counterinsurgency Wars. International Organization 63(1), 67-106.

MacKenzie, Todd A., Tor D. Tosteson, Nancy E. Morden, Therese A. Stukel, and A. James O'Malley (2014). Using instrumental variables to estimate a Cox's proportional hazards regression subject to additive confounding. Health Services and Outcomes Research Methodology 14(1-2), 54-68. 
Marshall, Monty G., Ted Robert Gurr, and Keith Jaggers (2016). Polity IV Project: Political Regime Characteristics and Transitions, 1800-2015. Available from http:/ / www.systemicpeace.org/inscrdata.html, last accessed on May 5, 2017.

Martínez-Camblor, Pablo, Todd Mackenzie, Douglas O. Staiger, Philip P. Goodney, and A. James O'Malley (2019). Adjusting for Bias Introduced by Instrumental Variable Estimation in the Cox Proportional Hazards Model. Biostatistics 20(1), 80-96.

Martinussen, Torben, Ditte Nørbo Sørensen, and Stijn Vansteelandt (2019). Instrumental variables estimation under a structural Cox model. Biostatistics 20(1), 6579.

Martinussen, Torben and Stijn Vansteelandt (2013). On collapsibility and confounding bias in Cox and Aalen regression models. Lifetime Data Analysis 19(3), 279-296.

Martinussen, Torben, Stijn Vansteelandt, Eric J. Tchetgen Tchetgen, and David M. Zucker (2017). Instrumental Variables Estimation of Exposure Effects on a Timeto-Event Endpoint Using Structural Cumulative Survival Models. Biometrics 73(4), 1140-1149.

Mehrl, Marius and Paul W. Thurner (2020). Military Technology and Human Loss in Intrastate Conflict: The Conditional Impact of Arms Imports. Journal of Conflict Resolution 64(4), 1172-1196.

Moore, Matthew (2012). Selling to Both Sides: The Effects of Major Conventional Weapons Transfers on Civil War Severity and Duration. International Interactions 38(3), 325-347.

Nordhaus, William, John R. Oneal, and Bruce Russett (2012). The Effects of the International Security Environment on National Military Expenditures: A Multicountry Study. International Organization 66, 491-513.

Pamp, Oliver and Andreas Mehltretter (2019). Know Thy Enemies, Know Thy Friends: In Search of Elusive Arms Races. Working Paper.

Pamp, Oliver, Lukas Rudolph, Paul W. Thurner, Andreas Mehltretter, and Simon Primus (2018). The build-up of coercive capacities: Arms imports and the outbreak of violent intrastate conflicts. Journal of Peace Research 55(4), 430-444.

Pettersson, Therése and Magnus Öberg (2020). Organized violence, 1989-2019. Journal of Peace Research.

Powell, Robert (1993). Guns, Butter, and Anarchy. American Political Science Review 87(1), 115-132.

Powell, Robert (2017). Taking Sides in Wars of Attrition. American Political Science Review 111(2), 219-236. 
Read, Derek (2010). Airpower in COIN: Can Airpower Make a Significant Contribution to Counter-Insurgency? Defence Studies 10(1-2), 126-151.

Regan, Patrick M. (2002). Third-Party Interventions and the Duration of Intrastate Conflicts. Journal of Conflict Resolution 46(1), 55-73.

Rogers, Elliott Leon (2012). What is the Role of Heavy Armor in the Army of 2020? A Monograph. School for Advanced Military Studies Monograph.

Ruhe, Constantin (2018). Quantifying Change Over Time: Interpreting Time-varying Effects In Duration Analyses. Political Analysis 26(01), 90-111.

San-Akca, Belgin (2015). Dangerous Companions: Cooperation between States and Nonstate Armed Groups (NAGs), v.04/2015.

San-Akca, Belgin (2016). States in Disguise: Causes of External State Support for Rebel Groups. New York: Oxford University Press.

Sawyer, Katherine, Kathleen Gallagher Cunningham, and William Reed (2017). The Role of External Support in Civil War Termination. Journal of Conflict Resolution 61(6), 1174-1202.

Schulhofer-Wohl, Jonah (2020). Quagmire in Civil War. Cambridge, UK: Cambridge University Press.

Singer, J. David, Stuart Bremer, and John Stuckey (1972). Capability Distribution, Uncertainty, and Major Power War, 1820-1965. In Bruce Russett (Ed.), Peace, War, and Numbers, pp. 19-48. Beverly Hills: Sage.

SIPRI (n.d.). Financial value of the global arms trade.

Sislin, John and Frederic S. Pearson (2001). Arms and Ethnic Conflict. Lanham, MD: Rowman \& Littlefield.

Sjolander, Arvid and Torben Martinussen (2019). Instrumental Variable Estimation with the R Package ivtools. Epidemiologic Methods 8(1), 1-20.

Smith, Niel A. and Nathan W. Toronto (2010). It's all the rage: Why mechanization doesn't explain COIN outcomes. Small Wars and Insurgencies 21(3), 519-528.

Stam, III, Allan C. (1996). Win, Lose, or Draw. Domestic Politics and the Crucible of War. Ann Arbor, MI: University of Michigan Press.

Sundberg, Ralph and Erik Melander (2013). Introducing the UCDP Georeferenced Event Dataset. Journal of Peace Research 50(4), 523-532.

Tchetgen, Eric J. Tchetgen, Stefan Walter, Stijn Vansteelandt, Torben Martinussen, and Maria Glymour (2015). Instrumental Variable Estimation in a Survival Context. Epidemiology 26(3), 402-410.

Tucker, David (2014). The End of Intelligence: Espionage and State Power in the Information Age. Stanford: Stanford University Press. 
Tullock, Gordon (1980). Efficient Rent Seeking. In James Buchanan, R. D. Tollison, and Gordon Tullock (Eds.), Toward a Theory of the Rent-Seeking Society, pp. 97-112. College Station, TX: Texas A\&M University Press.

UNEP-WCMC (2002). Mountains and Treecover in Mountain Regions 2002.

Uppsala Conflict Data Program (2018). UCDP Conflict Encyclopedia.

Vogt, Manuel, Nils-Christian Bormann, Seraina Rüegger, Lars-Erik Cederman, Philipp Hunziker, and Luc Girardin (2015). Integrating Data on Ethnicity, Geography, and Conflict: The Ethnic Power Relations Data Set Family. Journal of Conflict Resolution 59(7), 1327-1342.

Walter, Barbara F. (2009). Bargaining Failures and Civil War. Annual Review of Political Science 12, 243-261.

Wang, Linbo, Eric Tchetgen Tchetgen, Torben Martinussen, and Stijn Vansteelandt (2018). Learning Causal Hazard Ratio with Endogeneity. Working Paper.

Wood, Reed M (2010). Rebel capability and strategic violence against civilians. Journal of Peace Research 47(5), 601-614.

Wucherpfennig, Julian, Nils W. Metternich, Lars-Erik Cederman, and Kristian Skrede Gleditsch (2012). Ethnicity, the State, and the Duration of Civil War. World Politics 64(1), 79-115. 


\section{Appendix}

\section{A.1 Using Cox estimation to reproduce the main analyses}

Table A1 provides results of standard Cox proportional hazard estimator models to confirm robustness of the results from the causal Aalen additive hazards estimations. Again, arms imports are specified as lagged (models 1 and 2), 3-year averaged (models 3 and 4) and 5-year averaged variables (models 5 and 6). Additionally to the even-numbered models specified in line with the respective Aalen models from table 3, odd-numbered models show results without an interaction effect of arms imports and distance. Without this interaction, arms imports do not exhibit a significant effect in any model.

Regarding the even-numbered models, the results from the Cox estimation are similar to the Aalen estimations, with coefficients for the arms imports and distance variables being negative and statistically significant, and their interaction variable exhibiting a significant positive sign. Thus, the results presented above do not hinge on the choice of the estimator and assumptions on the proportionality or additive nature of the hazards.

The Cox results also corroborate the effects for most of the other variables. Notably, in all Cox models, rebels' terrorist tactics are found to prolong conflicts significantly, while the effect was not statistically significant in results based on the Aalen estimator. 
Table A1: Cox estimation results

\begin{tabular}{|c|c|c|c|c|c|c|}
\hline \multirow{3}{*}{$\log ($ Distance $)$} & \multicolumn{2}{|c|}{ Lagged } & \multicolumn{2}{|c|}{ 3-year avg. } & \multicolumn{2}{|c|}{ 5-year avg. } \\
\hline & (1) & (2) & (3) & (4) & (5) & (6) \\
\hline & $\begin{array}{c}-0.131^{* *} \\
(0.029)\end{array}$ & $\begin{array}{c}-0.196^{* *} \\
(0.032)\end{array}$ & $\begin{array}{c}-0.132^{* *} \\
(0.030)\end{array}$ & $\begin{array}{c}-0.205^{* *} \\
(0.035)\end{array}$ & $\begin{array}{c}-0.132^{* *} \\
(0.030)\end{array}$ & $\begin{array}{c}-0.212^{* *} \\
(0.038)\end{array}$ \\
\hline $\log (\mathrm{MCW}$ imports), lagged & $\begin{array}{l}-0.013 \\
(0.017)\end{array}$ & $\begin{array}{c}-0.181^{* *} \\
(0.069)\end{array}$ & & & & \\
\hline $\log (\mathrm{MCW}$ imports $)$, lagged $\times \log ($ Distance $)$ & & $\begin{array}{l}0.014^{*} \\
(0.006)\end{array}$ & & & & \\
\hline $\log$ (MCW imports), 3 yr. avg. & & & $\begin{array}{l}-0.010 \\
(0.020)\end{array}$ & $\begin{array}{c}-0.175^{* *} \\
(0.068)\end{array}$ & & \\
\hline $\log (\mathrm{MCW}$ imports), 3 yr. avg. $\times \log ($ Distance $)$ & & & & $\begin{array}{l}0.014^{*} \\
(0.006)\end{array}$ & & \\
\hline $\log$ (MCW imports), 5 yr. avg. & & & & & $\begin{array}{l}-0.018 \\
(0.024)\end{array}$ & $\begin{array}{c}-0.190^{*} \\
(0.079)\end{array}$ \\
\hline $\log (\mathrm{MCW}$ imports $), 5$ yr. avg. $\times \log ($ Distance $)$ & & & & & & $\begin{array}{l}0.014^{*} \\
(0.006)\end{array}$ \\
\hline $\log$ (Troop ratio) & $\begin{array}{c}0.116^{* *} \\
(0.037)\end{array}$ & $\begin{array}{c}0.117^{* *} \\
(0.036)\end{array}$ & $\begin{array}{c}0.116^{* *} \\
(0.038)\end{array}$ & $\begin{array}{c}0.116^{* *} \\
(0.037)\end{array}$ & $\begin{array}{c}0.118^{* *} \\
(0.038)\end{array}$ & $\begin{array}{c}0.118^{* *} \\
(0.037)\end{array}$ \\
\hline Group receives weapons support & $\begin{array}{c}-0.371^{* *} \\
(0.122)\end{array}$ & $\begin{array}{c}-0.377^{* *} \\
(0.123)\end{array}$ & $\begin{array}{c}-0.371^{* *} \\
(0.121)\end{array}$ & $\begin{array}{c}-0.374^{* *} \\
(0.122)\end{array}$ & $\begin{array}{c}-0.370^{* *} \\
(0.122)\end{array}$ & $\begin{array}{c}-0.373^{* *} \\
(0.122)\end{array}$ \\
\hline Group receives troops support & $\begin{array}{c}0.535^{* *} \\
(0.150)\end{array}$ & $\begin{array}{c}0.539^{* *} \\
(0.153)\end{array}$ & $\begin{array}{c}0.532^{* *} \\
(0.153)\end{array}$ & $\begin{array}{c}0.548^{* *} \\
(0.155)\end{array}$ & $\begin{array}{c}0.537^{* *} \\
(0.152)\end{array}$ & $\begin{array}{c}0.552^{* *} \\
(0.155)\end{array}$ \\
\hline Battle-related deaths per day in thousands & $\begin{array}{c}0.192^{* *} \\
(0.023)\end{array}$ & $\begin{array}{c}0.197^{* *} \\
(0.024)\end{array}$ & $\begin{array}{c}0.191^{* *} \\
(0.021)\end{array}$ & $\begin{array}{c}0.196^{* *} \\
(0.021)\end{array}$ & $\begin{array}{c}0.194^{* *} \\
(0.022)\end{array}$ & $\begin{array}{r}0.199^{* *} \\
(0.022)\end{array}$ \\
\hline Conflict over government (vs. territory) & $\begin{array}{c}-0.213^{+} \\
(0.117)\end{array}$ & $\begin{array}{c}-0.221^{+} \\
(0.121)\end{array}$ & $\begin{array}{c}-0.216^{+} \\
(0.117)\end{array}$ & $\begin{array}{c}-0.218^{+} \\
(0.121)\end{array}$ & $\begin{array}{c}-0.214^{+} \\
(0.116)\end{array}$ & $\begin{array}{c}-0.215^{+} \\
(0.121)\end{array}$ \\
\hline Group is excluded & $\begin{array}{c}-0.271^{*} \\
(0.118)\end{array}$ & $\begin{array}{c}-0.276^{*} \\
(0.121)\end{array}$ & $\begin{array}{c}-0.271^{*} \\
(0.119)\end{array}$ & $\begin{array}{c}-0.277^{*} \\
(0.123)\end{array}$ & $\begin{array}{c}-0.272^{*} \\
(0.118)\end{array}$ & $\begin{array}{r}-0.276^{*} \\
(0.122)\end{array}$ \\
\hline Democracy dummy & $\begin{array}{l}-0.237 \\
(0.172)\end{array}$ & $\begin{array}{l}-0.220 \\
(0.170)\end{array}$ & $\begin{array}{l}-0.237 \\
(0.173)\end{array}$ & $\begin{array}{l}-0.229 \\
(0.172)\end{array}$ & $\begin{array}{l}-0.234 \\
(0.173)\end{array}$ & $\begin{array}{l}-0.233 \\
(0.172)\end{array}$ \\
\hline GDP p.c. growth & $\begin{array}{c}0.132 \\
(0.558)\end{array}$ & $\begin{array}{c}0.288 \\
(0.562)\end{array}$ & $\begin{array}{c}0.113 \\
(0.569)\end{array}$ & $\begin{array}{c}0.218 \\
(0.570)\end{array}$ & $\begin{array}{c}0.099 \\
(0.576)\end{array}$ & $\begin{array}{c}0.191 \\
(0.578)\end{array}$ \\
\hline $\log (\mathrm{GDP}$ p.c.) & $\begin{array}{l}-0.053 \\
(0.067)\end{array}$ & $\begin{array}{l}-0.045 \\
(0.065)\end{array}$ & $\begin{array}{l}-0.058 \\
(0.070)\end{array}$ & $\begin{array}{l}-0.051 \\
(0.068)\end{array}$ & $\begin{array}{l}-0.049 \\
(0.070)\end{array}$ & $\begin{array}{l}-0.041 \\
(0.068)\end{array}$ \\
\hline $\log$ (Population) & $\begin{array}{l}-0.088 \\
(0.059)\end{array}$ & $\begin{array}{c}-0.114^{*} \\
(0.056)\end{array}$ & $\begin{array}{l}-0.090 \\
(0.058)\end{array}$ & $\begin{array}{c}-0.109^{+} \\
(0.057)\end{array}$ & $\begin{array}{l}-0.082 \\
(0.059)\end{array}$ & $\begin{array}{c}-0.097^{+} \\
(0.058)\end{array}$ \\
\hline Group is terrorist group & $\begin{array}{c}-0.366^{* *} \\
(0.123)\end{array}$ & $\begin{array}{c}-0.374^{* *} \\
(0.123)\end{array}$ & $\begin{array}{c}-0.366^{* *} \\
(0.123)\end{array}$ & $\begin{array}{c}-0.368^{* *} \\
(0.123)\end{array}$ & $\begin{array}{c}-0.366^{* *} \\
(0.122)\end{array}$ & $\begin{array}{c}-0.365^{* *} \\
(0.122)\end{array}$ \\
\hline Mountainous terrain index & $\begin{array}{c}-0.218^{*} \\
(0.110)\end{array}$ & $\begin{array}{c}-0.195^{+} \\
(0.111)\end{array}$ & $\begin{array}{c}-0.223^{*} \\
(0.110)\end{array}$ & $\begin{array}{c}-0.210^{+} \\
(0.109)\end{array}$ & $\begin{array}{c}-0.219^{*} \\
(0.110)\end{array}$ & $\begin{array}{c}-0.210^{+} \\
(0.108)\end{array}$ \\
\hline Cold War dummy & $\begin{array}{c}-0.464^{* *} \\
(0.132) \\
\end{array}$ & $\begin{array}{c}-0.479^{* *} \\
(0.134) \\
\end{array}$ & $\begin{array}{c}-0.470^{* *} \\
(0.131) \\
\end{array}$ & $\begin{array}{c}-0.488^{* *} \\
(0.132) \\
\end{array}$ & $\begin{array}{c}-0.453^{* *} \\
(0.135) \\
\end{array}$ & $\begin{array}{c}-0.463^{* *} \\
(0.136) \\
\end{array}$ \\
\hline No. of observations & 1683 & 1683 & 1683 & 1683 & 1683 & 1683 \\
\hline No. of conflict dyads & 418 & 418 & 418 & 418 & 418 & 418 \\
\hline No. of failures & 378 & 378 & 378 & 378 & 378 & 378 \\
\hline
\end{tabular}

Note: ${ }^{*}\left({ }^{+},{ }^{* *}\right)$ indicates $p<.05(.1, .01)$ 